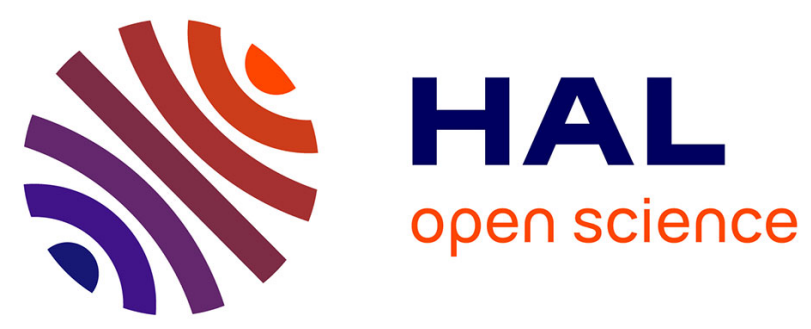

\title{
GEOTECTONIC SIGNIFICANCE OF GNEISSIC AMPHIBOLITES FROM THE VEMA FRACTURE ZONE, EQUATORIAL MID-ATLANTIC RIDGE
}

José Honnorez, Catherine Mével, Raymond Montigny

\section{- To cite this version:}

José Honnorez, Catherine Mével, Raymond Montigny. GEOTECTONIC SIGNIFICANCE OF GNEISSIC AMPHIBOLITES FROM THE VEMA FRACTURE ZONE, EQUATORIAL MIDATLANTIC RIDGE. Journal of Geophysical Research, 1984, 89 (B13), pp.379-390. insu-01894668

\section{HAL Id: insu-01894668 \\ https://hal-insu.archives-ouvertes.fr/insu-01894668}

Submitted on 12 Oct 2018

HAL is a multi-disciplinary open access archive for the deposit and dissemination of scientific research documents, whether they are published or not. The documents may come from teaching and research institutions in France or abroad, or from public or private research centers.
L'archive ouverte pluridisciplinaire HAL, est destinée au dépôt et à la diffusion de documents scientifiques de niveau recherche, publiés ou non, émanant des établissements d'enseignement et de recherche français ou étrangers, des laboratoires publics ou privés. 
JOURNAL OF GEOPHYSICAL RESEARCH, VOL. 89, NO. B13, PAGES 11,379-11,400, DECEMBER 10, 1984

GEOTECTONIC SIGNIFICANCE OF GNEISSIC AMPHIBOLITES FROM THE VEMA FRACTURE ZONE, EQUATORIAL MID-ATLANTIC RIDGE

Jose Honnorez

Rosenstiel School of Marine and Atmospheric Sclence, University of Miaml, Florida

Catherine Mével

Laboratolre de Pétrologie, Universite Plerre et Marie Curie, Paris, France

Raymond Montigny

Laboratolre de Paleomagnétisme, Institut de Physique du Globe, Universite Louls Pasteur Strasbourg, France

\begin{abstract}
A large collection of gnelssic amphibolites was recovered by two close dredge hauls from the deepest part of the north facing slope of the transverse ridge forming the south wall of the Vema Fracture Zone. Serpentinites and varlous types of gabbroic rocks ranging from undeformed slightly uralitized gabbros and norites to flaser and mylonitlc gabbros were associated with the gneissic amphibolites (In the shallowest of the dredge hauls). Petrological studies indicate that the amphibolites were derlved from similar gabbrolc rocks that reequilibrated under stress in the conditions of the amphibolite facles. On the other hand, the associated metagabbros display sequences of secondary minerals, indicating complex cooling and cataclastic histories without reaching metamorphic equilibrium. We tentatively suggest that the gneissic amphibolites and assocfated metagabbros formed in a vertical shear zone generated in oceanic layer 3 by tectonism associated with the Vema Fracture Zone. Hydrothermal c1rculation of seawater along the highly permeable shear zone was activated by magmatic intruslons. $\mathrm{K} / \mathrm{Ar}$ dating suggests, within relatively large analytical uncertainties, that the amphibolite metamorphism took place $10 \mathrm{~m} . \mathrm{y}$. ago, i.e., at a time when the dredging sites were located in the vicinity of the spreading center.
\end{abstract}

\section{Introduction}

The nature of the lower oceanic crust is still largely a matter of speculation mainly because the International Program of Ocean Drilling (IPOD) phase of the Deep Sea Drilling Project (DSDP) fell short of reaching lower crustal depths. Therefore our source of knowledge of the deep crust rests upon ocean floor geophysical properties, dredge hauls from the major fracture zones, and comparison with ophiolite complexes. However, all three sources supply only indirect information. On the one hand, the geophysical properties are inferred from either large-scale surveys and experiments or small-scale laboratory measurements of dredged or cored samples. On the other hand, metamorphic rocks dredged from the major transform faults have always been suspected to represent crustal material which had been generated or, at least, modi-

Copyright 1984 by the American Geophysical Union.

Paper number 4B0776.

0148-0227/84/004B-0776\$05.00 fled by processes restricted to fracture zones. Whether transform faults provide sections in "normal" oceanic crust is still debated [Thompson and Melson, 1972; Bonatt1 and Honnorez, 1976; Francheteau et al., 1976; Fox et a1., 1976; Bonatti et al., 1979]. Fina1ly, comparisons with the lower portions of ophlolite complexes are controversial because of the postoceanic evolution and the questionable origin of the ophiolites.

Nevertheless, several models have been suggested which attempt to explain the geophysical properties of the deeper crust in terms of rock types recovered in dredge hauls or observed in ophiolite complexes. It should be emphasized that probably most of these models are, at least local$1 y$, correct. According to these models the lower oceanic crust, also called "layer $3, "$ is quite variable in thickness and nature. Three main rock types and thelr varlous combinations are most often mentioned as major constituents of layer 3: partly serpentinized peridotites [Hess, 1959], gabbros [Ewing and Ewing, 1959; Gutenberg, 1959; Ra1tt, 1963; Fox et al., 1973] and a varlety of hornblende-bearing basic and metabasic rocks. The latter include "dyke swarms mostly metamorphosed to the hornblende bearing facies" [Cann, 1970] and "amphibolites and hornblende gabbros" [Chrlstensen, 1970, 1972; Christensen and Salisbury, 1975].

Most of the oceanic metamorphic rocks which have been dredged so far from the seafloor are characterized by preserved igneous textures and nonequilibrium mineral assemblages. It seems that ocean floor metamorphism is related to c1rculation of hydrothermal solutions along open fractures in absence of stress [Cann and Funne11, 1967; Melson et a1., 1968; Cann, 1969, 1979; Miyash1ro et a1., 1971; KIrst, 1976; Humphris and Thompson, 1978]. However, oceantc metamorphic rocks have been recovered from the seafloor in which preexisting igneous textures and mineralogy have been obliterated. These rocks display strong follation and sometimes multiple brecciation, mylonitization, or folding. They were dredged mostly, but not exclusively, from transform fault zones [Honnorez and Bonatti, 1975].

True amphibolites in which 1gneous textures have been completely obliterated were collected by two dredge hauls from the Vema Fracture Zone (equatorial Atlantic) during two different cruises: $P 7003$ of the $R / V$ P11lsbury (University of Miami [Honnorez et a1., 1977] and $\mathrm{CH78}$ of the Jean Charcot (Centre National pour 1 'Exploitation des Oceans (CNEXO)). The purpose of th1s paper is to 
amphibolites and associated metagabbros from the active portion of the Vema Fracture Zone and to determine through petrological evidence and $\mathrm{K} / \mathrm{Ar}$ dating the conditions and age of the metamorphic event. The implications suggested by their presence in such a tectonic environment are also discussed. The physical and magnetic properties of the same rock collection will be presented in another paper discussing the feasibility for gnefssic amphibolites to represent a major component of layer 3 .

\section{Oceanic Amphibolites and Nomenclature}

Matthews et al. [1965] appear to be the first ones to have briefly described "banded gabbros" from the crest of the Carlsberg Ridge, near a transcurrent fault. They were described in great detall by Cann and V1ne [1966], who ca11 them "banded hornblende gabbros." They are made up of alternating green hornblende and An 50 plagioclase lenticular bands and rarer clinozoisite lenses. It is not known whether the plagloclase is metamorphic or an igneous relict.

Bodganov and Ploshko [1967] described in detal1 two fragments of "banded amphibolite" dredged with metagabbros from the Romanche Fracture Zone. Both rocks are formed by alternating bands of brown or greenish-brown hornblende and acidic plagioclase. Hornblende is partiy retrograded to actinolite. Ploshko et al. [1970] described the accompanying "gabbro-amphibolites" where 1gneous textures are well preserved and magmatic relic minerals are abundant. They contaln common brown or green hornblende along with actinolite.

Aumento et al. [1971] reported two distinct mineral assemblages in foliated "amphibolites" from the Mid-Atlantic Ridge, near $45^{\circ} \mathrm{N}$. The first type is made up of green hornblende and plagioclase (oligoclase-andesine), with magnetite, sphene, epldote, biotite, and sericitized orthoclase. It is attributed to "the lower grade of almandine amphibolite facies." The second type also contalns diopside and would correspond to "the highest grade of amphibolite facies." The presence of quartz, biotite, and seriticized orthoclase in the $45^{\circ} \mathrm{N}$ amphibolites is most unusual for oceanic rocks even though Aumento et a1. do not consider these samples as erratics.

"Gnelssic gabbros" and "amphibole schists" are mentioned but not described by Thayer [1969] as having been dredged from the Mid-Atlantic Ridge, at $30^{\circ} \mathrm{N}$. Miyashiro et al. [1971] briefly described "gnelssic and banded metagabbros" from the crestal region of the Mid-Atlantic Ridge adjacent to the Atlantis Fracture Zone, at $30^{\circ} \mathrm{N}$. Plagloclase and pyroxene porphyroclastic relicts coexist with interstitial brown hornblende. Miyashiro et a1 also mentioned, without describing it, a "schistose amphibolite" from the fracture zone.

Unusual "amphibolites" were dredged in the Atlantic from the base of the Palmer Ridge, at $42^{\circ} \mathrm{N}$ [Cann and Funne11, 1967; Cann, 1971], which are made up of green hornblende and calcic plagioclase of unspectfled origin (Igneous or metamorphic?). Igneous pyroxene relicts are abundant. The peculiarity of these amphibolites is that the Igneous textures of the parent rocks are well preserved and no follation was observed. Cann and Funne11 [1967] and Cann [1971] indicate that the amphibolites are derived from basalts and doler1tes.
"Banded and granular amphibolites" from fault scarps of the Mid-Atlantic Ridge, at $6^{\circ} \mathrm{N}$, had been mentioned by Bonatti et al. [1970, 1971], but when studied in detail, the same rocks were called "follated or banded" and "granular amphibolitized or amphibolitic metagabbros" [Bonatti et al.,1975] and were ascribed to the greenschist-amphibolite transitional facles. Jehl [1975] extensively described and analyzed a "schistose amphibolite" from the Gibbs Fracture Zone. It is made up of green hornblende, "intermediate" plagloclase, and magnetite.

A "follated metagabbronorite" from hole 334 , DSDP leg 37 to the Mid-Atlant1c Ridge was studied in great detall by Helmstaedt and Allen [1977]. The rock is made up of granulated relict plagloclase, orthopyroxene, and clinopyroxene, the latter being partly replaced by tremolite and actinolitic hornblende. The rock was interpreted as having been deformed at temperatures ranging from granulite to amphibolite facies during the cooling of the gabbros even though it lacks the amphibolite facies mineral paragenesis.

Ito [1979] and Ito and Anderson [1983] studied a stratigraphically controlled collection of plutonic rocks which were collected by submersible from the Mid-Cayman Rise along two vertical profiles spanning 700 m water depth. The rocks range from gabbros to amphibolites, and all are more or less deformed, but the deformation is irregularly distributed within a hand specimen or even a thin section. Most of the rocks have undergone partial recrystallization and display amphibolite mineral paragenes1s. An average of $15 \%$ of the total rock collection was transformed to amphibolites, but the samples which have completely reached equilibrium under the conditions of the amphibolite facles are exceptional. Metamorphism would have taken place during the cooling of the gabbros, and hornblende would have formed from igneous plagioclases and pyroxenes between $500^{\circ}$ and $750^{\circ} \mathrm{C}$, whereas olivine would have been altered at temeratures ranging from $700^{\circ}$ to $200^{\circ} \mathrm{C}$. Oxygen isotope study of minerals separated from these rocks [Ito and Clayton, 1983] shows that plag1oclase and amphiboles have exchanged oxygen with seawater or altered seawater $\left(\delta^{18} 0<3 / 00\right)$, whereas pyroxene and ollvine relicts did not. Moreover, the decrease in extent of the 1sotoplc exchange between plagioclase and seawater and the decrease in amphibole abundance with crustal depth indicate that the water circulation rapldly decreased with crustal depth: the water/rock ratio dropped from 1.7 to 0.2 over a 300-m crustal depth Interval. Hence, Ito and Clayton [1983] Infer that the seawater circulation diminishes rapidly with depth and hence that the seawater circulation was essentially restricted to the upper portion of the plutonic layer and seawater-derlved solutions barely reached the bottom of this layer.

One can see from this brlef review that a large variety of hornblende-bearing rocks recovered from the seafloor have been called "amphibolites" and that as pointed out by Honnorez and Ito [1979] and Cann [1979], the term amphibolite has of ten been used indiscriminantly and, sometimes, misused. Some of the rocks are gabbros containing hornblendes that are thought to be of igneous origin [e.g., Malcolm, 1979; Prichard and Mitche1l, 1979]. Such rocks are by no means amphibolites. Most of the so-called amphibolites are partly metamorphosed gabbros which have not reached full 
equilibrium in the conditions of the amphibolite facles. Such rocks often display relicts of a gabbrolc mineralogy and texture [e.g., Cann and Funne11, 1967; Ploshko et al., 1970; Miyashiro et al., 1971; Bonatt1 et al., 1975; Helmstaedt and A11en, 1977]. Oceantc rocks which completely recrystallized in the conditions of the amphibollte facies are much less commonly reported. In re-sulted from the intense deformation and recrystallization of the parent Igneous rocks which can only be assumed [e.g., Cann and Vine, 1966; Bodganov and Ploshko, 1967; Jehl, 1975]. Gabbros completely reequilibrated in the amphibolite facies without losing their original Igneous texture are the rarest [Ito, 1979].

It is therefore important to define accurately the terminology used in the context of this paper. We call "amphibolite" a metamorphic rock whose major mineral paragenesis, hornblende, and calcic plagloclase indicate that it reequilibrated under the conditions of the amphibolite facles. Such rocks may or may not exhibit follation depending on the intensity of deformation and are accordingly qualified as "gneissic" or "with gabbrolc texture," respectively. In the latter case, the name is followed by the textural name of the parental 1gneous rock. All of the other part1y metamorphosed rocks displaying igneous relict minerals are called "hornblende-bearing flaser metagabbros" or "hornblende-bearing metagabbros," respectively. Table 1 presents the nomenclature used in the present paper to designate oceanic amphibolites and associated rocks.

Sample Location and Tectonic Setting

The material studied in this paper consists of a set of gabbros, metagabbros, and gneissic amphibolites (Figure 1) collected in two dredge hauls from the base of the north facing wall of the transverse ridge forming the south wall of the Vema Fracture Zone at about $11^{\circ} \mathrm{N}$ in the Atlantic Ocean (see F1gure 2). One dredge haul by the University of Miaml's R/V Pillsbury in 1970 recovered mainly mylonitized serpentinites and cataclastic gabbros with very few amphibolites and only two basalt fragments from depths ranging from 2050 to $2850 \mathrm{~m}$ below the crest of the transverse ridge. In 1978, a dredge haul that CNEXO's R/V Jean Charcot recovered at about $15 \mathrm{~km}$ east of the preceding

TABLE 1. Proposed Nomenclature of Metamorphic Hornblende-Bearing Metabasites From the Oceanic Crust
Complete

Recrystallization

(Equilibrium

Paragenesis)
Partial

Recrystallization

(Metastable

Paragenesis)

$\begin{array}{ccc}\begin{array}{c}\text { Dynamic } \\ \text { hydrothermal } \\ \text { metamorphism }\end{array} & \begin{array}{c}\text { Gneissic } \\ \text { anphibolites }\end{array} & \begin{array}{c}\text { Hornblende-bearing } \\ \text { flaser gabbros }\end{array} \\ \begin{array}{c}\text { Static } \\ \text { hydrothermal } \\ \text { metamorphism }\end{array} & \begin{array}{c}\text { Amphibolites } \\ \text { with gabbroic } \\ \text { textures }\end{array} & \begin{array}{c}\text { Hornblende-bearing } \\ \text { metagabbros }\end{array} \\ & & \end{array}$

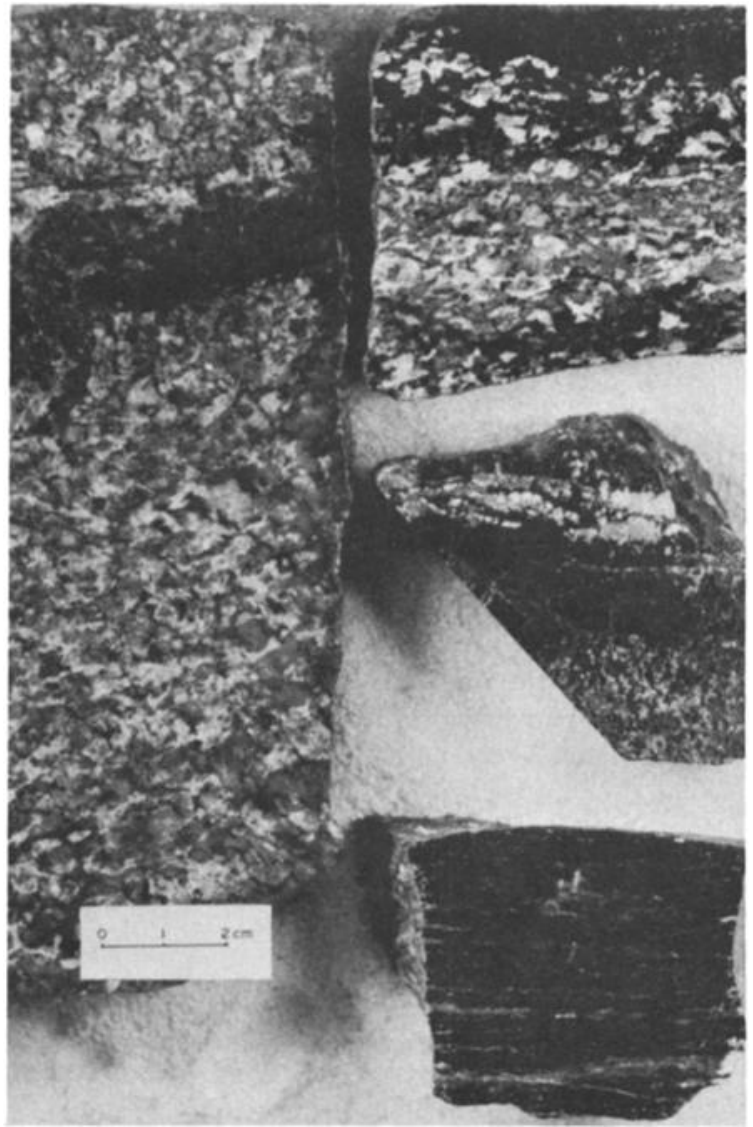

Fig. 1. Hand specimen showing the gradation from metagabbro to gneissic amphibolite. (left) undeformed uralitized gabbro showing a dark hornblende "vein" (P7003-19AA). (right) (top to bottom) uralitized 1ineated gabbro (P7003-19DD), flaser gabbro (P7003-19G) and gneisstc amphibolite (P7003-19E) in which magmatic texture is no more visible.

site and about 2900 a below the ridge crest included numerous amphibolites and deformed serpentinites with very few gabbros, which includes a Fe, Ti-rich gabbronorite and leucoferrodiorite [Ohnenstetter and Ohnenstetter, 1980]. The rocks from the Vema Fracture Zone are compared with a single amphibolite specimen (sam-ple Gs7309-51K) from the foot of the northern wall of the Romanche Fracture Zone. Table 2 summarizes the geographic location, the bathymetric informa-tion, and the lithologic composition of the three dredge hauls where amphibolites were found.

The Vema Fracture Zone offsets the Mid-Atlantic Ridge left laterally by about $320 \mathrm{~km}$. It is marked by a narrow and almost straight east-west trough filled with about $l \mathrm{~km}$ of sediments. The sediment/water interface lies $5 \mathrm{~km}$ below sealeve1. The topography of the Vema Fracture Zone has been described by Heezen et al. [1964] and Van Ande1 [1969] and Van Andel et al. [1967, 1971]. The petrologic information about rocks dredged from the fracture zone walls can be found in papers by Bonatt et a1. [1971, 1974], Bonatti and Honnorez [1976], Honnorez and Kirst [1975], Melson and Thompson [1971], Prinz et al. [1976], and Thompson and Me1son [1972]. The Vema Fracture valley is bound by two steep walls with $30-50^{\circ}$ 


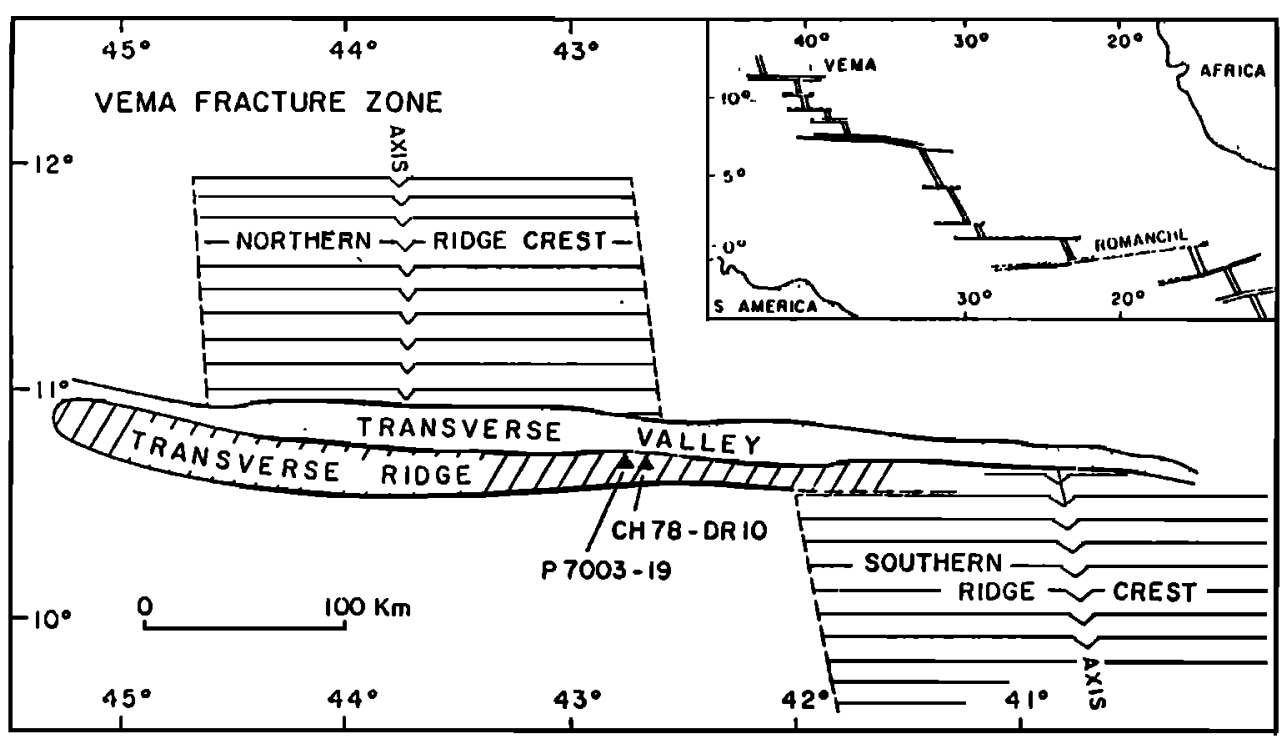

F1g. 2. Structural sketch map of the Vema Fracture Zone and location of the dredge hauls.

slopes, but the topography of the two walls is strikingly contrasted. The north wall does not display any topographic anomaly and appears to be a representative but probably disrupted section through the oceanic crust [Bonatti and Honnorez, 1976] whose surface progressively slopes away from the Mid-Atlantic Ridge following the Sclater et a1. [1971] relationship between distance from spreading axis and water depth.

On the other hand, the south wall corresponds to a narrow (10-25 km wide) transverse ridge running parallel to the valley and reaching up to 550 m beneath sealevel. Similar transverse ridges are common features of transform faults which displace slow-spreading mid-ocean ridges [Bonatti et al., 1979; Bonatti and Chermak, 1981]. Van Andel et al. [1971] have noted that this topograpic anomaly is not a constructional feature built up by volcanic activity. It has been interpreted as resulting from the uplift or "protusions" of an upper mantle derived serpentinite body into the fracture zone [Bonatt1 and Honnorez, 1971, 1976; Thompson and Melson, 1972; Honnorez et a1., 1975; Bonatti, 1976, 1978]. Slabs of crustal material riding "plggyback" on top of serpentinite protrusion were uplifted and eventually emerged [Honnorez et a1., 1975; J. Honnorez, unpublished, manuscript, 1977].

On the basis of regular wide-beam precision depth recorder surveys it was initially assumed [e.g. Bonatt1 et al., 1971; Bonatt1 and Honnorez, 1976; Bonatt1, 1978] that these steep and smooth wa11s corresponded to one or two faults with throws of a few kilometers. High-resolution studies with multibeam side scan sonars ("seabeam") during leg 78 of the $R / V$ Jean Charcot [H. D. Needham et a1., unpublished data, 1979] indicate that the southern face of the south wall is made up of numerous small fault scarps with throws of a few hundred meters and narrow ledges in accord with the model proposed by Francheteau et al. [1976], whereas the northern face appears to be formed by two or three fault scarps separated by two terraces.

The transverse ridge forming the south wall of the Vema Fracture Zone was Interpreted as a "stagnant" crustal block, 1.e., a wedge of basement material which does not spread as fast as the surrounding seafloor [Bonatt1 and Honnorez, 1971l. A tentative Mesozolc age was suggested by Honnorez et al. [1975] for the shallow water limestone capping the transverse ridge.

\section{Sample Descriptions}

In hand specimen, the amphibolites display irregularly spaced discontinuous white streaks of plagioclase up to $5 \mathrm{~mm}$ thick in a dark brownishblack amphibole background. Both the amphibole cleavages and the layer alternation impart a strong follation to the rock. The grain size varles considerably. Some samples actually look like fine-grained mylonites, others like mediumgrained gneisses (grains up to $1 \mathrm{~mm}$ in diameter). All of the specimens are coated with a thin manganese crust.

Microscopically, the mineral assemblage is simple and constant. The observed paragenesis is Ca-plagloclase + hornblende \pm cllnopyroxene + ilmenite, typical of the amphibolite facles. Only the Romanche sample is devold of ilmenite. All the minerals appear metamorphic except possibly apatite and very scarce zircon which are $1 \mathrm{r}-$ regularly distributed in the rocks and are concentrated in lenses aligned with the follation. Both minerals may be interpreted as broken magatic crystals or as recrystallized crystals after magmatic grains.

Two types of amphibolites can be distinguished on the basis of their texture: gneissic and mylonitic amphibolites. The mineral paragenesis of the 15 studied amphibolite samples is summarlzed in Table 3 .

\section{Gnetssic Amphibolites}

Gneissic amphibolites are by far the most common type and are well illustrated by sample CH78Dr10-20. Plagioclase forming the white layers 
(Figure 3) usually occurs as granular, slightly zoned crystals up to $0.5 \mathrm{~mm}$ in diameter. Larger crystals, up to $1 \mathrm{~mm}$ long, are occasionally present and are commonly characterized by an undulatory extinction. Hornblende is usually zoned from 1ight brown cores to green rims, although an inverse zonation is observed in a few cases. Trains of small 1lmenite crystals emphasize the follation, and their proportion varies from sample to sample. Apatite and zircon may also occur but are always very rare. In some samples, thin layers of small rounded clinopyroxene crystals (50200 un In diameter) are observed lining up parallel to the follation. They never form elongated porphyroclasts as in flaser gabbros such as those described by Helmstaedt and Allen [1977]. They are particularly abundant in sample CH78Dr1077 (Figure 4). The clinopyroxenes appear to be metamorphic in origin.

In samples $\mathrm{P} 7003-19 \mathrm{E}$ and $19 \mathrm{~F}$, amphibole-rich layers consist of homogeneous brown to ollve brown hornblende crystals forming a decussate texture along with randomly scattered interstitial ilmenite grains (Figure 5). Rare rounded zircon crystals are observed between the hornblende grains. The plagloclase rich streaks are made up of trains of equant, rounded plagioclase $0.2 \mathrm{~mm}$ in diameter. Plagloclase crystals display strong zoning and patchy extinction in P7003-19F but are homogeneous in P7003-19E.

\section{Mylonitic Amphibolites}

Four samples of very fine grained mylonitic amphibolite exhtbit a dark green, almost black color in hand specimen. Rounded hornblende and plagfoclase porphyroclasts up to $1 \mathrm{~mm}$ in diameter occur in a finer-grained ( $50 \mu \mathrm{m}$ average diameter) matrix made up of green hornblende, plagloclase, ilmentte, and, in CH78Dr10-81 only, clinopyroxene (F1gure 6).

Most of the gneissic and mylonitic amphibolite samples appear to have been slightly affected by a retrograde metamorphic event. Minerals typical of the greenschist facies such as chlorite, actinolite, epidote, albite, prehnite, and sphene conmonly occur either as lenticular zones parallel to the follation or as parallel walled veins crossing the latter. Sphene comnonly rims the ilmenite crystals. Iron hydroxides (?) are abundant in sample CH78Dr10-75, where they form rusty patches. A zeolite tentatively identified as analcite forms veins in sample GS7309-51K. In the vicinity of the veins, hornblende may grade into actinolite or be lighter brown in color with occasional green patches. A third type of retrogressive mineral assemblage is observed in sample P7003-19F, where a poikiloblastic sodic plagloclase (An 20\%) encloses small hornblende crystals and "corroded" Ca-plagioclase grains. Clusters of prehnite microcrystals occur within or around the sodic plagloclase.

It is important to notice that the retrograde event occurred after deformation, as demonstrated by the veins intersecting the follation. On the whole, the retrograde metamorphic minerals do not account for much of the amphibolite except in sample CH78Dr10-126 where the plagloclase is largely replaced by albite, sericite, and prehnite. The mineralogical assemblage of the gneissic amphibolites are summarized in Table 3 .

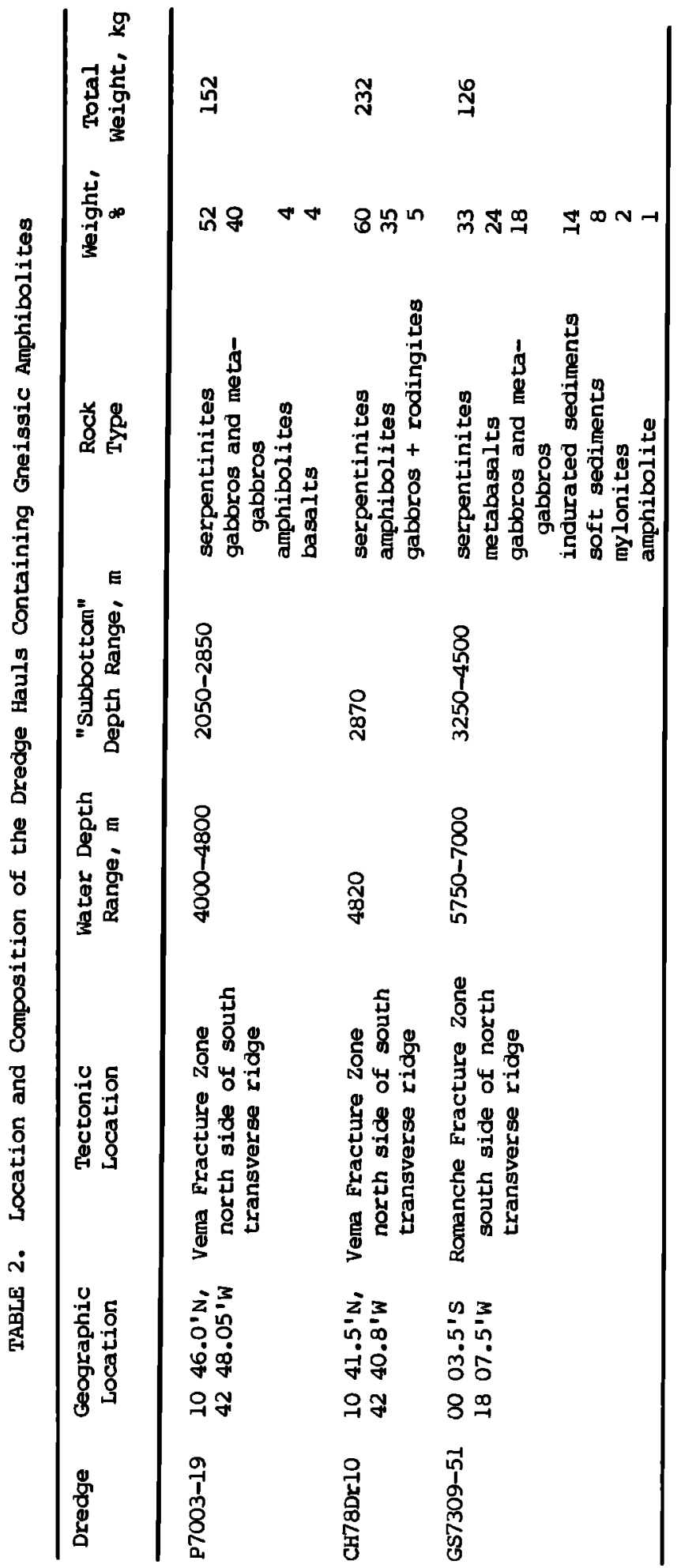


TABLE 3. Mineralogical Composition of the Studied Samples of Amphibolites

\begin{tabular}{|c|c|c|c|c|}
\hline Dredge Haul & Sample & Rock Type & Typomorphic Paragenesis & Retromorphic Minerals \\
\hline $\begin{array}{l}\text { CH78Dr10 } \\
\text { Vena } \\
\text { Fracture } \\
\text { Zone }\end{array}$ & $\begin{array}{l}\text { Drlo-14 } \\
\text { Drlo-18 } \\
\text { Drlo-20 } \\
\text { Drlo-75 } \\
\text { Drlo-83 } \\
\text { Drlo-86 } \\
\text { Drlo-16 } \\
\text { Drlo-23 } \\
\text { Dr10-77 } \\
\text { Dr10-81 } \\
\text { Drlo-82 }\end{array}$ & $\begin{array}{l}\text { gneissic amphibolite } \\
\text { without cpx } \\
\text { gneissic amphibolite } \\
\text { without cpx } \\
\text { gneissic amphibolite } \\
\text { without cpx } \\
\text { gneissic amphlbolite } \\
\text { without cpx } \\
\text { gneissic amphibolite } \\
\text { without cpx } \\
\text { gneissic amphibolite } \\
\text { without cpx } \\
\text { gneissic amphibolite } \\
\text { without cpx } \\
\text { gneissic amphibolite } \\
\text { with cpx } \\
\text { gneissic amphibolite } \\
\text { with cpx } \\
\text { gneissic amphibolite } \\
\text { with cpx } \\
\text { mylonitic } \\
\text { amphibolite } \\
\text { mylonitic } \\
\text { amphibolite }\end{array}$ & 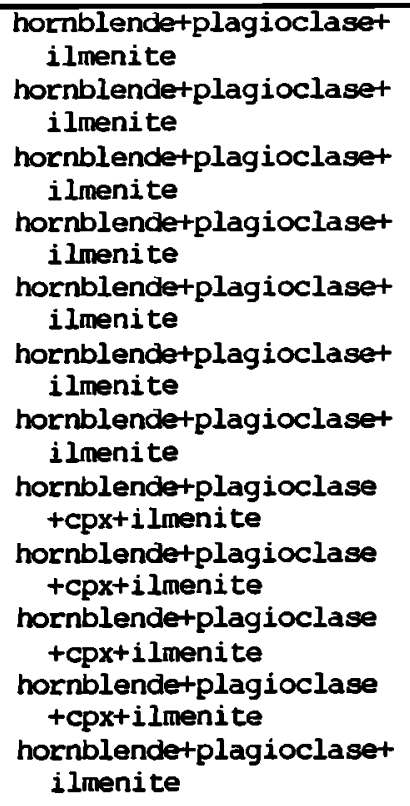 & $\begin{array}{l}\text { actinolite+chlorite+sphene } \\
\text { white mica+sphene } \\
\text { sphene } \\
\text { sphene+chlorite+epidote }\end{array}$ \\
\hline $\begin{array}{l}\text { P7003 } \\
\text { Vema } \\
\text { Fracture } \\
\text { Zone }\end{array}$ & $19 E$ & $\begin{array}{l}\text { gneissic amphibolite } \\
\text { w1 thout cpx } \\
\text { gneissic amphibolite } \\
\text { without cpx }\end{array}$ & $\begin{array}{l}\text { hornblende+plagioclase } \\
\text { +ilmenite } \\
\text { hornblende+plagioclase } \\
\text { +ilmenite traces }\end{array}$ & $\begin{array}{l}\text { actinoli te+prehni te+epidotet } \\
\text { chlorite+sphene+albite } \\
\text { epidote+sphene+prehni tet } \\
\text { chlorite+albite+actınolite+ } \\
\text { quartz }\end{array}$ \\
\hline $\begin{array}{l}\text { GS7309 } \\
\text { Romanche } \\
\text { Fracture } \\
\text { Zone }\end{array}$ & $51 K$ & $\begin{array}{l}\text { gneissic amphibolite } \\
\text { without cpx }\end{array}$ & hornblende+plagioclase & epidote+chlorite \\
\hline
\end{tabular}

\section{Assoctated Gabbros and Metagabbros}

A complete transition exists between undeformed gabbros and gneissic rocks, Indicating that recrysallization progressed with deformation of the gabbrolc rocks up to the point where the follated rocks do not contain any igneous relict mineral or texture. The numerous gabbroic rocks found along with the gnelsic amphibolites in dredge haul P7003-19 display a continuous range of textures from undeformed 1gneous fabrics of various types to cataclastic, mylonitic, and gneissic textures.

The main minerals of the least deformed gabbros (e.g., P7009-19BB,X,V) are subhedral to euhedral, calcium-rich plagloclase (An 55 to 70 ), anhedral augitic clinopyroxene, titanomagnetite, and ilmentte as "exsolution" lamellae and/or discrete granules. Forsteritic olivine and hypersthene are much less frequent except in two samples (P7009$19 \mathrm{I}$ and $\mathrm{Y}$ ) which are an augite-bearing norite and a troctolitic metagabbro, respectively. The amount of opaques varies from samples that are $\mathrm{Fe}$, Ti oxide-rich gabbros to others which contain almost no opaques.

Plagloclase displays kinked twin planes, undulatory extinction, and incipient mortar structure. The granulation of the igneous plagioclase is accompanfed by its replacement by more sodic phases.
Amphibole composition and distribution suggest a complex evolution. Three main types of occurrences are observed:

1. Both clinopyroxenes and orthopyroxenes contain blebs of reddish brown, strongly pleochroic amphibole which are kaersutitic and therefore thought to be of magmatic orfgin. It is remarkable that this amphibole is preserved even when pyroxene 18 completely replaced by actinolite or green hornblende.

2. Rarely, clinopyroxenes and orthopyroxenes (e.g., in sample P7003-19I) are direct1y rimmed by discontinuous brown or ollve-green hornblende.

3. More commonly, clinopyroxene, generally displaying orange to brown stains (iron hydroxides and/or smectites), is partly or completely replaced by multiple rims of amphibole: 1) an 1nner, finely fibrous tremolite-actinolite mosaic clouded with secondary magnetite dust; this rim is almost colorless near the pyroxene core and progressively becomes greener as it grades into 2) an intermediate rim of green to ollve-green fibrous actinolitic hornblende without secondary opaques; this rim becomes outwardly more homogeneous, 3) a well-crystallized (i.e., optically continuous) zoned brown hornblende whose terminations eventually extend into bluish-green chlorine-rich hornblende which also fills velns cutting the adjacent plagioclase crystals (Figure 7). A similar 


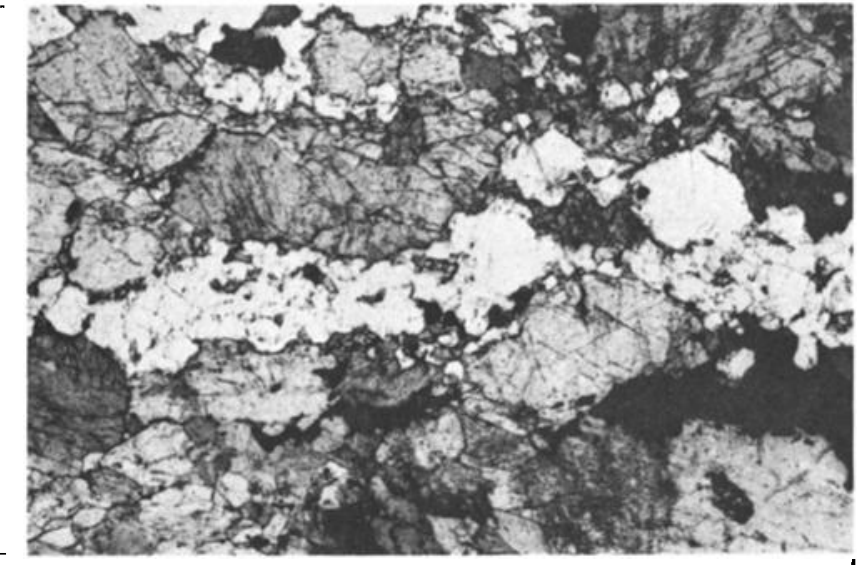

F1g. 3. CH78Dr10-20. Gneissic amphibolite with alternating layers of plagioclase (white) and hornblende (dark gray). Ilmentte (black) underlines the follation. (Photomicrograph with uncrossed nicols.)

sequence of amphibole rims has been described by Bonatti et al. [1975] in metagabbros from the crest of the Mid-Atlantic Ridge, at $6^{\circ} \mathrm{N}$.

The orthopyroxene is often altered into a $\mathrm{mix}-$ ture of Iron oxyhydroxides and/or smectites (iddingsite?) starting from the crystal outlines and a crack network. The ultimate result is an $1 \mathrm{~d}-$ dingsitic looking boxwork. The rare olivine crystals are generally almost completely replaced efther by an orange "Iddingsite" or by a mixture of talc(?) and secondary magnetite.

The primary titanomagnetite is extensively replaced by hematite, maghemite, goethite, and lepidocrocite. It is often surrounded by sphene. Large 11 menite grains are associated with numerous smaller (recrystallized?) ilmenite granules. I1menite is often partly replaced by sphene and, more rarely, rutile. Large ilmenite crystals exhibit undulatory extinction.

Several samples of uralitized gabbros are strongly lineated and/or crossed by narrow shear zones (samples P7003-19AA, CC, DD, and KKK). The

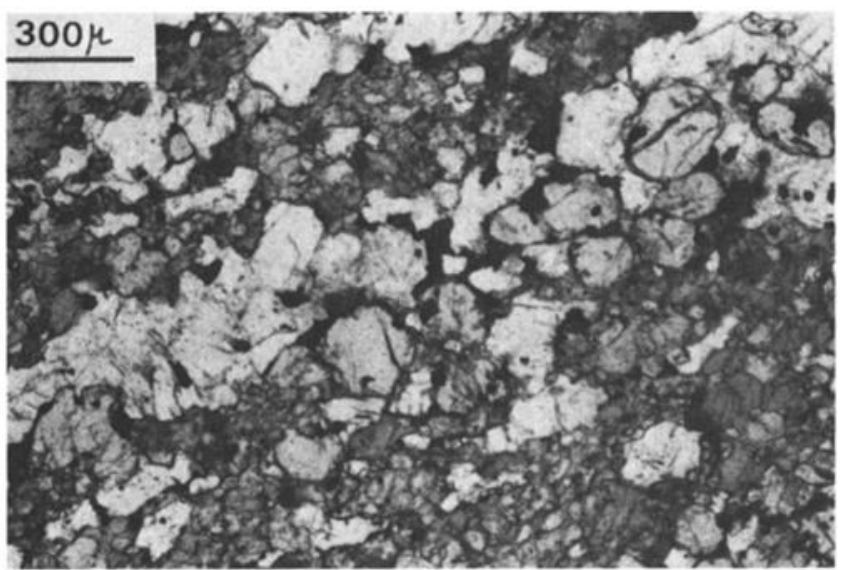

F1g. 4. CH78Dr10-77. Layer rich in rounded crystals of clinopyroxene (11ght gray) In a gnelssic amphibolite made up of plagioclase (white), hornblende (dark gray), and 1lmentte (black). (Photomicrograph with uncrossed nicols.)

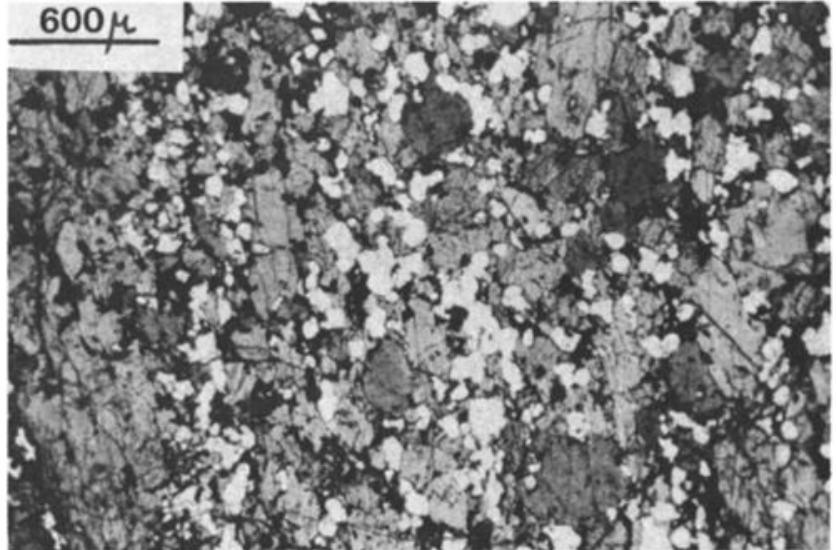

Fig. 5 P7003-19E. Gneissic amphibolite with decussate texture (white plagloclase, gray hornblende, black ilmenite). (Photomicrograph with uncrossed nicols.)

shear zones are marked by diffuse blackish hornblende rich veins up to $2 \mathrm{~cm}$ thick which are parallel to the lineation. The "veins" are essentially made up of idioblastic ollve-green or bright to bluish-green hornblende with rare sma11 plagloclases and opaque granules. Close to the veins the plagioclase is more finely granulated than in the remainder of the rock, and the clinopyroxenes are completely replaced by various green amphiboles ranging from actinolites to actinolitic hornblendes to hornblendes. Strongly pleiochrolc orange to yellow scales up to $0.25 \mathrm{~mm}$ in length of a micalike smectite fill out the interstices between other minerals and cracks or are scattered within the plagioclase.

The flaser gabbros (e.g., samples P7003-19G, H, and S) display textures ranging from place to place, from that of the lineated metagabbros close to the hornblende velns to that of mylonitic gabbros. They are characterized by a further granu-

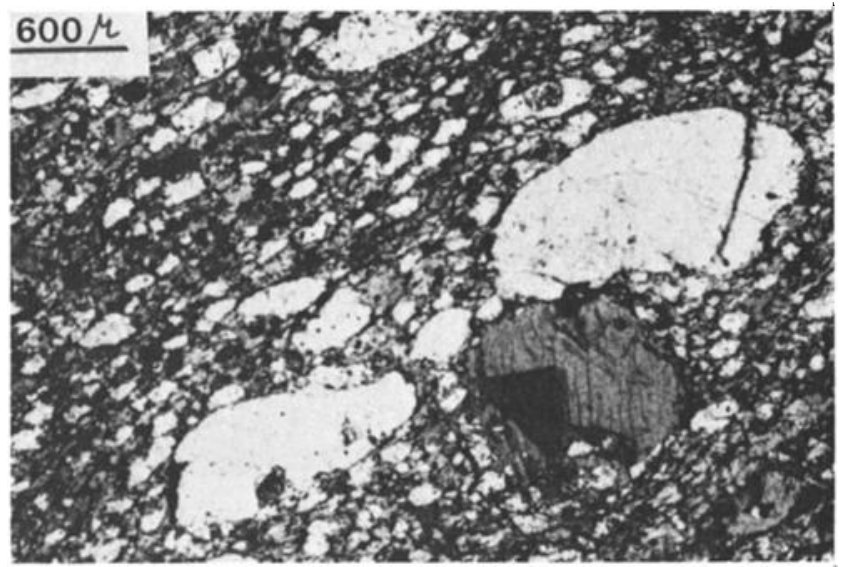

Fig. 6. CH78Dr10-81. Mylonitic amphibolite with rounded porphyroclasts of hornblende (dark gray) and plagioclase (white) in a fine-grained matrix consisting of plagloclase, hornblende, and 1Imenite (black). Ilmenite is particularly abundant in this rock which has the bulk composition of an iron, titanium-rich gabbro. (Photomicrograph with uncrossed nicols.) 


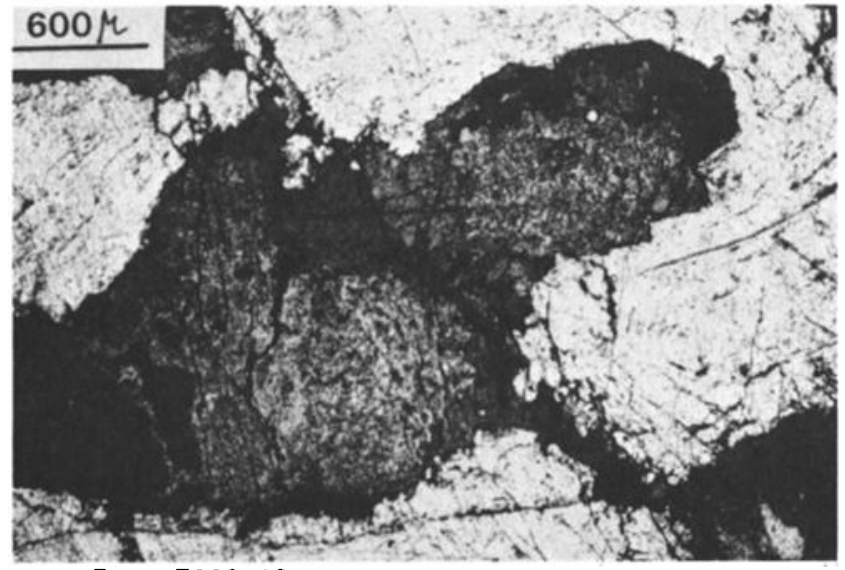

F1g. 7. P7003-19AA. Replacement of magmatic clinopyroxene in an undeformed uralitized gabbro. The center of the pyroxene pseudomorph is replaced by actinolite, rimmed by brown hornblende then green chlorine-rich hornblende projecting into veins. The magmatic plagioclase (white) is preserved. (Photomicrograph with uncrossed nicols.).

lation of the plagloclase, an almost complete replacement of the clinopyroxene (by varfous green amphiboles), and a massive breakdown of the opaques to leucoxene or sphene. The dominant amphibole is a tan to olive-green pleochroic hornblende contalning scattered small patches of kaersutitic amphibole. Rounded apatite grains $0.5 \mathrm{~mm}$ in diameter occur sometimes within the hornblende augen. Fractures in the plagioclase porphyroclasts are filled with chlorite and smectites or are crisscrossed by a network of narrow velnlets of more sodic plagloclase. In sample P7003-19G, albite is the only plagioclase.

The mylonftic metagabbros (e.g., P7003-19Q) are made up of alternating dark and thick and clear and thin bands. The dark bands are formed by a blackish green almost opaque matrix composed of extremely fine (from $0.003 \mathrm{~mm}$ to submicroscopic) granules of green amphiboles and opaque minerals. The clear bands are mainly made up of plagloclase granules. Lenses of granulated apatite also occur. Rounded Ca-rich plagloclase and green amphibole augen displaying undulatory extinction are observed. The amphibole augen are rarely zoned with a fibrous actinolitic rim surrounding a monocrystalline hornblende core. The latter exceptionally contains a small clinopyroxene rellct with the characteristic yellow stain (F1gure 8). Scaley, pleochroic (gold yellow to orange) smectite occurs through the rock either assoctated with the green amphibole or, more rare$1 y$, forming lenses by itself. The undulatory extinction of the various amphiboles, the presence in some augen of an actinolite rim surrounding hornblende cores, or the fact that scaley smectite forms lenses indicate that the last shearing stage followed a retrograde metamorphism of (partly?) amphibolitized metagabbros.

Several types of secondary mineral veinlets are observed in various gabbrolc rocks associated with the gneissic amphibolites:

1. The most frequent veinlets are made up of pleochroic yellow-orange smectites. These veins. exist in all of the various types of gabbros and metagabbros, and they always appear to have formed the last.

2. Less frequent are olive to bluish-green hornblende veins crossing both plagioclase and uralitized clinopyroxenes.

3. Two of the flaser metagabbro samples (P7003-19H and S) contain up to $1 \mathrm{~mm}$ thick rims of sutured quartz, with scattered epidote, and vermiculated chlorite grading into yellow-orange smectite.

\section{Analytical Data}

\section{Mineral Chemistry}

Samples of gneissic amphibolite have been selected for microprobe analyses: four without clinopyroxene (DR10-126, Dr10-75, and P7003-19E and F), three with clinopyroxene (Dr10-23, Dr1077 , and Dr10-16), and one mylonite (Dr10-81). They also represent the range of bulk rock compositions. For comparison, minerals from the Romanche Fracture Zone gneissic amphibolite sample GS7309-51K have also been analyzed.

The analyses on CH78Dr10 samples have been carried out on a CAMECA MS46 microprobe, using natural minerals as standards. Elements concentrations have been calculated with the EMPADR VII program [Rucklidge and Gasparini, 1969]. The analyses on the P7003-19 samples were carried out on an ARL electron microprobe equipped with an energy dispersive $X$ ray spectrometer and using natural minerals as standards. The Reed and Ware [1975] correction procedure was used.

Amphiboles. The amphibole compositions are quite homogeneous in a given amphibolite sample but vary from sample to sample from magnesiohornblende to ferro-hornblende according to Leake's [1978] classification (Table 4).

Independently of the amphibolites bulk compositions, amphiboles are quite similar with respect to their $A 1$ IV,$T 1$, and alkalis contents which have been demonstrated to depend mostly on physical conditions [Shido and Miyashiro, 1959; Liou et al., 1974; Raase, 1974; Spear, 1975]. In all but one of the amphibolites from the Vema

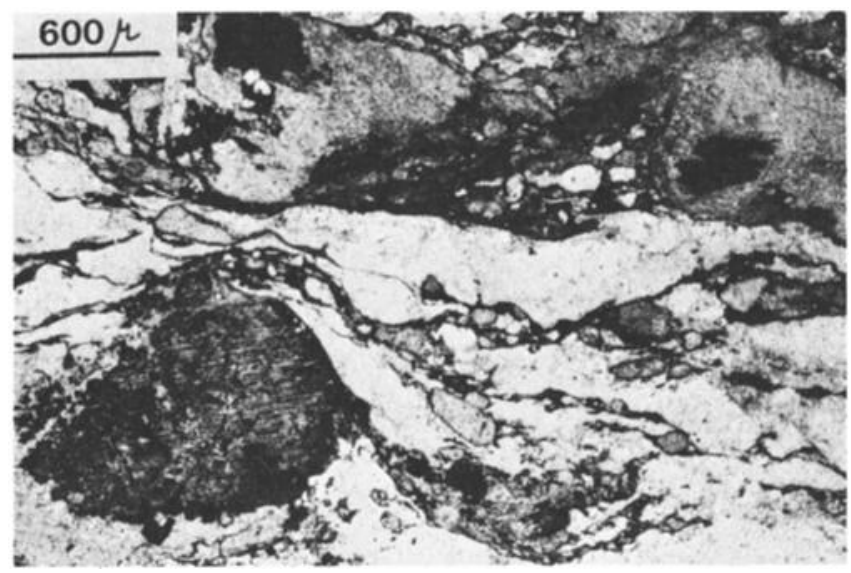

Fig. 8. P7003-19H. Flaser gabbro. The rock is sheared, and a follation is visible. However, magmatic clinopyroxene is still present as a porphyroclast. (Photomicrograph with uncrossed nicols.) 

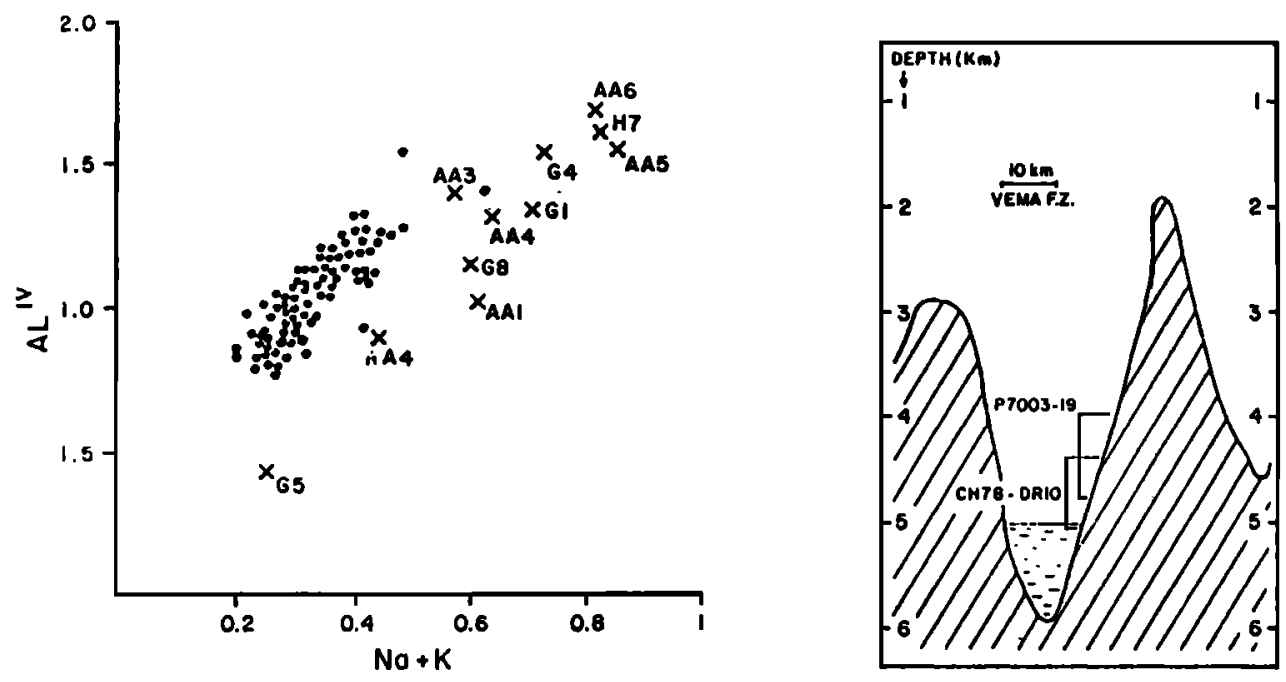

F1g. 9. $\mathrm{Al}^{\mathrm{IV}}$ versus $\mathrm{Na}+\mathrm{K}$ diagram for amphiboles. Dots, all amphiboles in gneissic amphibolites; crosses, amphiboles in assoclated metagabbros (AA, P7003-19AA, uralitized gabbro; G, P7003-19G, flaser gabbro; H, P7003-19H, flaser gabbro).

Fracture Zone, the amphibole $T 1$ content varies between 0.1 and 0.2 cations per 23 oxygens, and is not correlated with the titanium content of the rocks. This is well explained by the presence of another titanium-bearing phase, ilmenite, in the rocks. Titanium-rich rocks contain abundant 11mente, while the titanium content of the amphibole essentially depends on physical conditions and is consistent with upper amphibolite facies [Raase, 1974]. This is not true in sample P7003$19 \mathrm{E}$, which is extremely rich in titanium $(8.8 \%$ $\mathrm{TiO}_{2}$ ). In this case, the $\mathrm{TiO}_{2} / \mathrm{FeO}$ ratio of the rock is too high for 1lmenite to use up all of the Ti. Hence the amphiboles are more titaniferous in this sample than in any others. The titanium content of amphiboles from the Romanche sample (G57309-51K) is much lower $(0.07 \%)$ and in the absence of 11menite in the rock (Table 3) may be dependent on the bulk rock composition $\left(\mathrm{TiO}_{2}=\right.$

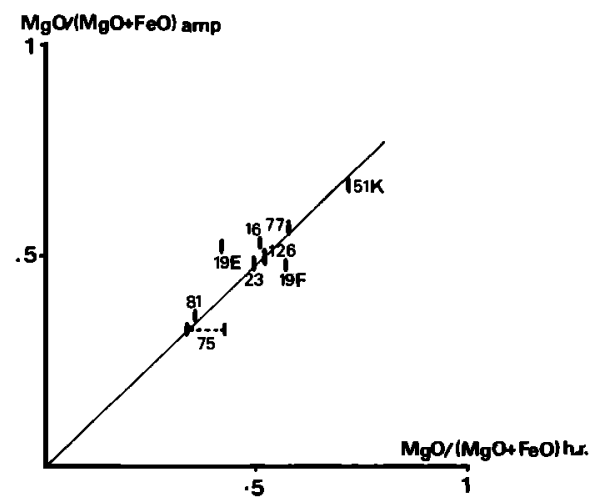

Fig. 10a. $\mathrm{MgO} /(\mathrm{MgO}+\mathrm{FeO})$ of amphiboles versus buik host, in amphibolite rocks.51K, GS7309-51K; $19 \mathrm{E}$ and $19 \mathrm{~F}, \mathrm{P} 7003-19 \mathrm{E}$ and $19 \mathrm{~F}$, respectively; the others are CH78Dr10-16, 23, 75, 77,81 and 126, respectively. The dashed line joins the representative plot of host rock with its present oxidation ratio (right) and with an oxidation ratio of 0.4 (left). See text for explanation.
$0.30 \%$ ). In zoned crystals, $\mathrm{Al}^{\mathrm{IV}}, \mathrm{T} 1$, and alkalis decrease from the light brown center to the green periphery (Figure 9). This can be interpreted as a progressive lowering of the temperature as the crystal grows. The chlorine content is below detection.

The $\mathrm{Mg} / \mathrm{Fe}$ ratio of amphiboles in the gnelssic amphibolites varies from sample to sample. Figure $10 \mathrm{a}$ demonstrates that it is related to bulk rock compositions. All the representative points scatter about a single line on the Fe-Mg diagrams except sample Dr10-75. Th1s rock is characterized by a high oxidation $\left(\mathrm{Fe}_{2} \mathrm{O}_{3} / \mathrm{FeO}=1.2\right.$ ) which may be related to retrograde alteration. Actually, when its oxidation ratio is fixed at 0.4 (value for sample Dr10-81, rock having about the same Iron content), the $\mathrm{MgO} / \mathrm{MgO}+\mathrm{FeO}$ of the rock decreases: the representative point is shifted toward the left and plots on the same line as the others.

There is no significant compositional difference between the various porphyroclasts and the small grains of the matrix of the Dr10-81 mylonite. This observation suggests that the metamorphic conditions did not vary during the mylonitization.

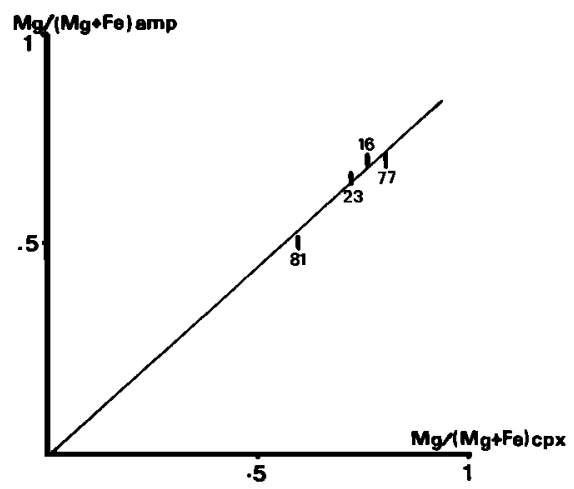

Fig. 10b. $\mathrm{Mg} /(\mathrm{Mg}+\mathrm{Fe})$ of amphibole versus assoclated pyroxene in amphibolites. 


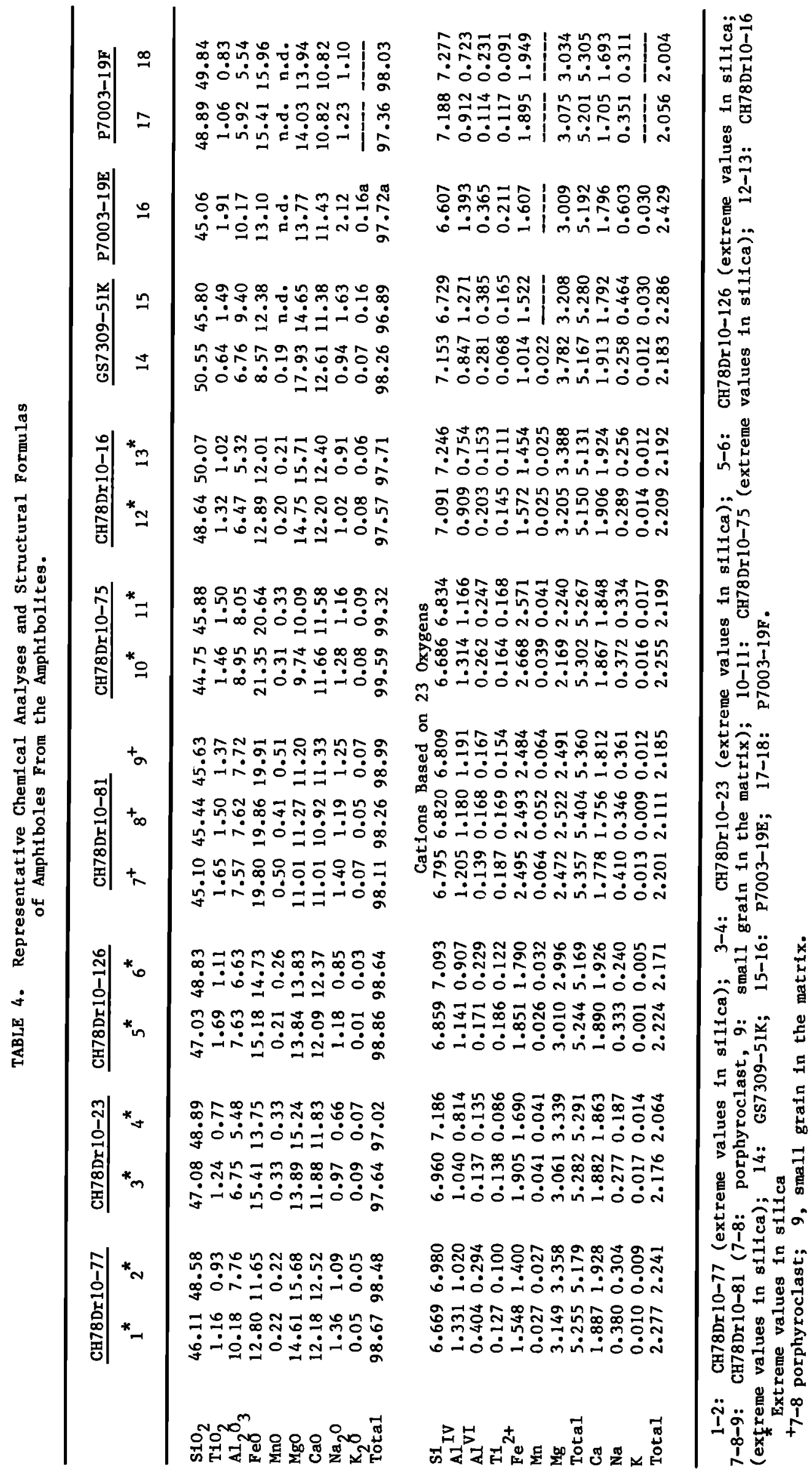


For comparison, microprobe analyses of selected amphiboles of the associated metagabbros are presented in Table 5. P7003-19AA is a lineated uralitized gabbro (host) containing a green hornblende ve1n. The amphiboles in the host metagabbro is a ferro (to ferroan) pargasitic hornblende, whereas 1t varles from magnesio- to ferro-hornblende and ferro-edentitc hornblende in the veins. In the flaser gabbro sample P7003-19H, two amphiboles were identifled as magnesio-hornblende and magnesian hastingsitic hornblende. In the mylonitic metagabbro P7003-19G the amphiboles range from actinolite to ferro-edinitic hornblende to magnesian hastingsitic hornblende to ferro-hornblende.

Compared with the hornblende of the gneissic amphibolite, the amphiboles of associated metagabbros are characterlzed by a much wider fleld of composition, suggesting a lack of reequilibration during metamorphism. It is remarkable that in an Al versus alkalis diagram (Figure. 9), representative points are systematically shifted toward more alkaline compositions (1.e., sodic, for the potassium content is always low). Moreover, the ferro-hornblendes and ferro-edentic hornblendes in the veins contain abundant chlorine (e.g., Table 5, analysis. 6). The significance of this observation is discussed in the following chapter.

Clinopyroxene. Clinopyroxene from the gneissic amphibolites is apparently metamorphic judging from textural relationships. The clinopyroxene composition is very homogeneous in a given sample (Table 6) but varies somewhat among various specimens. All the pyroxenes belong to the diopsidehedenbergite series. They are always $\mathrm{Al}^{\mathrm{IV}}$, alkali-, and Ti-poor, as expected from metamorphic pyroxenes [Girardeau and Mevel, 1982]. Like the amphiboles, the $\mathrm{Mg} / \mathrm{Fe}$ ratio of the metamorphic pyroxenes is related to the bulk rock composition (see Figure. 10b).

plagloclase. The rock texture indicates that the plagioclase coexisting with hornblende in the gneissic amphibolites is also secondary and has recrystallized under stress. Only in samples Dr 10-23 and Dr10-81 are there large crystals scattered in a finer-grained matrix of plagioclase and displaying undulatory extinction which could be interpreted as magmatic porphyroclasts in a recrystallized matrix. Plagioclases from all rocks are calcic, but their composition varies from one specimen to another, generally ranging from An 48 to An 66. Their iron and potasslum contents are always low, even in the large crystals, again typical of secondary plagloclase $(0.4$ and $0.5 \%$, respectively).

In sample P7003-19E the plagloclase grains are homogeneous, as Indicated by the lack of compositional difference between the core and the rim of the simple grains (Table 7). Unzoned highly ca1clc plagloclases also occur in specimens Dr10-77 and GS7309-51K. Both amphibolites are characterlzed by a very high $\mathrm{CaO} / \mathrm{Na}_{2} \mathrm{O}$ content. As will be discussed later, these two rocks are interpreted either as metamorphosed rodingites or adcumulate gabbros devoid of or containing little Fe-T1 oxtdes. In the other rocks, plagioclases are commonly zoned from a calcic core to a more sodic rim (Table 7). In the mylonite Dr10-81 the sma11 plagloclase grains of the matrix are similar in composition to the more sodic rims of zoned porphyroclasts.

The relationship between the An content of the plagloclase and the $\mathrm{Na}_{2} \mathrm{O}$ content of the bulk rock is not simple. Calcic plagloclase is stable at the temperature under which metamorphism occurred. The An content of secondary plagioclase may thus be dependent on the composition of the primary plagloclase it recrystallized from.

The polkiloblastic plagloclase porphyroclasts of sample P7009-19F contain less than 20\% An. Albite (An 6) has been analyzed in retromorphic veins from Dr10-126 in equilibrium with epidote. No Intermediate composition between calclc plagioclase and retrograde albite was found, indicating a gap between the high-temperature metamorphism and the low-temperature retromorphic event.

\section{Bulk Rock Chemistry}

Table 8 presents the bulk rock chemical analyses of 19 gneissic amphibolites from the Vema Fracture Zone and the single amphibolite from the Romanche Fracture Zone. The bulk rock compositions have to be discussed with caution in terms of comparison with magmatic equivalents. It is clear from an AFM diagram (see Figure 11) that the range of chemical compositions of amphibolites is similar to those of oceanic gabbros and metagabbros [Bonatti et al., 1971; Miyashiro and Shido, 1980; Prinz et a1., 1976; J Honnorez, unpublished. data 1977]. Table 8 shows that the rocks are rather heterogeneous in composition. The most variable elements are titanfum, fron, silica, and aluminum. Five rocks (CH78Dr10-81, Dr10-75, P7003-19E, $Q$, and $A A$ ) are titanium- and Iron-rich and correlatively aluminum- and silicapoor. Their compositions are consistent with those of iron- and titanium-rich gabbros. On the other hand, three other amphibolite samples (GS7309-51R and CH78Dr10-13 and 129) are very titanium poor $\left(<1 \% \mathrm{THO}_{2}\right)$ and relatively iron poor $\left(<8.6 \% \mathrm{FeO}^{\mathrm{T}}\right)$. Such rocks probably correspond to adcumulate gabbros almost completely devold of opaques. The potassium content of the gneissic amphibolites is always very low, except in CH78Dr10-126 in which calcle plagloclase is partly altered to secondary white mica: its higher potassium concentration is thus explained by a relatively low-temperature secondary alteration.

\section{Age of Metamorphism}

Dating oceanic metamorphic rocks is a difficult process because none of the minerals they contain are favorable to isotopic dating methods. K/Ar dates have nevertheless been attempted on isolated amphiboles and plagloclases and on bulk rock samples. The analytical precision of the results is rather poor because potassium concentrations are very low in both amphiboles and plagloclases and thus in whole rocks.

Plagioclases and hornblendes were separated from the 80-160 um fractions by heavy liquids and magnetic separation. Different sieve sizes, however, were used for samples Dr10-20 and Dr10-77. They are mentioned in the table of results. An 8mm-diameter core was directly fused for $\mathrm{Ar}$ analysis of the whole rock Dr10-23. On the other hand, the Ar analysis of the whole rock Dr10-83 was performed on the 250-350 im fraction after ultrasonic cleaning.

The analytical procedure, more extensively described elsewhere [Westphal et al.,1979], was the 


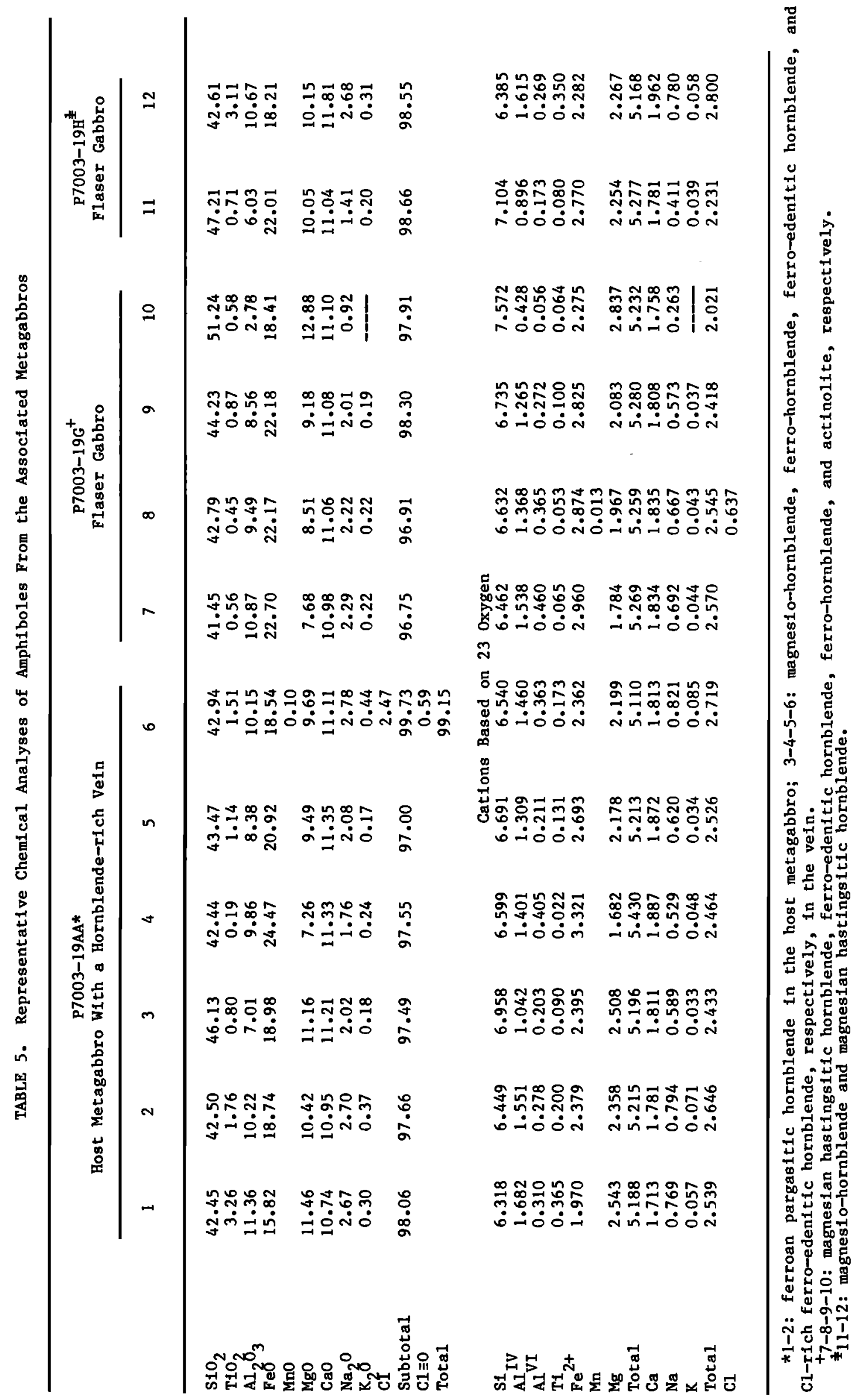


TABLE 6. Representative Chemical Analyses of Clinopyroxenes From the Amphibolites.

\begin{tabular}{|c|c|c|c|c|}
\hline & CH78Dr10-77 & CH78Dr10-23 & CH78Dr10-81 & CH78Dr10-16 \\
\hline $\begin{array}{l}\mathrm{SiO}_{2} \\
\mathrm{TiO}_{2} \\
\mathrm{Al}_{2} \mathrm{O}_{3} \\
\mathrm{FeO}_{3} \\
\mathrm{MnO} \\
\mathrm{MgO} \\
\mathrm{CaO} \\
\mathrm{Na}_{2} \\
\mathrm{Total}\end{array}$ & $\begin{array}{r}51.67 \\
0.24 \\
1.94 \\
7.02 \\
0.21 \\
14.87 \\
23.42 \\
0.10 \\
99.47\end{array}$ & $\begin{array}{r}51.63 \\
0.11 \\
0.70 \\
9.76 \\
0.45 \\
13.65 \\
23.01 \\
0.32 \\
99.63\end{array}$ & $\begin{array}{r}50.64 \\
0.21 \\
1.01 \\
14.45 \\
0.72 \\
11.49 \\
21.10 \\
0.25 \\
99.87\end{array}$ & $\begin{array}{r}52.54 \\
0.25 \\
1.32 \\
8.03 \\
0.23 \\
14.49 \\
23.69 \\
0.33 \\
100.88\end{array}$ \\
\hline $\begin{array}{l}\mathrm{Si} \\
\mathrm{A} 1 \mathrm{IV} \\
\mathrm{Al}^{\mathrm{VI}} \\
\mathrm{Ti}^{2} \\
\mathrm{Fe}^{2+} \\
\mathrm{Mn} \\
\mathrm{Mg} \\
\mathrm{Ca} \\
\mathrm{Na} \\
\mathrm{Tota1}\end{array}$ & $\begin{array}{l}1.931 \\
0.069 \\
0.016 \\
0.007 \\
0.219 \\
0.007 \\
0.828 \\
0.938 \\
0.007 \\
2.022\end{array}$ & $\begin{array}{c}\text { Cations based on } 6 \\
1.954 \\
0.031 \\
0.003 \\
0.309 \\
0.014 \\
0.770 \\
0.933 \\
0.024 \\
2.053\end{array}$ & $\begin{array}{l}1.947 \\
0.046 \\
0.006 \\
0.465 \\
0.023 \\
0.659 \\
0.869 \\
0.019 \\
2.041\end{array}$ & $\begin{array}{l}1.946 \\
0.054 \\
0.004 \\
0.007 \\
0.249 \\
0.007 \\
0.800 \\
0.940 \\
0.023 \\
2.030\end{array}$ \\
\hline
\end{tabular}

following: argon was analyzed by isotopic dilution mass spectrometry. Potassium was measured by flame photometry with a lithium internal standard. Ages were computed with the $K$ decay constants proposed by Steiger and Jaeger [1977]. plus-minus figures were estimates of analytical precision at one standard deviation. They were calculated following the procedure given by Cox and Dalrymple [1967].

The results of $\mathrm{K}-\mathrm{Ar}$ age analyses are given in Table 9. The following section will be devoted to assessing the geological meaning of the dates yielded by the three systems investigated in this study, hornblendes, plagioclases, and whole rocks.

The hornblendes Dr10-81 and Dr10-20 display evidence of alteration (chloritization?) that may explain both their high contamination by atmospheric argon and their relatively low age values, $7.8 \pm 3.7$ and $7.1 \pm 2.3 \mathrm{m.y}$. , respectively. The other hornblendes can be regarded as fresh. Two of them (1.e., Dr10-77 and Dr10-16) yield ages of the same order of magnitude, $8.6 \pm 1.4$ and $9.6 \pm$ $1.5 \mathrm{~m} . \mathrm{y} .$, respectively. The amphibole, Dr10-83, on the other hand, displays a higher value of 13.1 $\pm 1.8 \mathrm{~m} . \mathrm{y}$. Is there any real difference between the ages of Dr10-20 and Dr10-83? Dalrymple and Lanphere's [1969] critical value test, at $95 \%$ confidence (according to which there is a real difference between the calculated ages of two minerals), is not quite conclusive. If one assumes then that Dr10-16, Dr10-20, Dr10-77, Dr1081 , and Dr10-83 have been metamorphosed contemporaneously, the event would have probably occurred between 8 and $12 \mathrm{Ma}$.

One plagloclase, Dr10-16, gives a $\mathrm{K}-\mathrm{Ar}$ age, $10.9 \pm 2.5 \mathrm{~m} . \mathrm{y} .$, close to that of the coexisting hornblende which gave $9.6 \pm 1.5 \mathrm{~m} \cdot \mathrm{y}$. On the other hand, the other plagioclase, Dr10-83, yields an age of $19.6 \pm 4.1 \mathrm{~m} . \mathrm{y}$. This discrepancy might be due to an occurrence of excess argon in the feld- spar. The analytical uncertainties, however, preclude any definite conclusion.

In spite of high analytical errors the bulk rock sample Dr10-83 yields a calculated age that is compatible with that of the amphibole separate. On the other hand, bulk rock sample Dr1023 indicates an age of $17.8 \pm 1.6 \mathrm{~m} . \mathrm{y}$. The lack of data on the mineral phases, however, prevents giving any sound and definite interpretation of that age.

Two observations lead us to conclude that a metamorphic event has occurred about 10 m.y. ago: the minerals from sample Dr10-16 yield almost concordant ages close to this value, and the age determination of five hornblendes fall in this range. A $10 \pm 2 \mathrm{~m} \cdot \mathrm{y}$. age has been determined by U-He method on sample P7003-19E originating from the same area (D.E. Fisher, personal communication 1983). It has to be noted that two independent methods give similar answers for the same type of rock.

\section{Discussion}

\section{Parental Rocks}

The gneissic amphibolites are completely devold of relict igneous textures and minerals; hence the nature of their parental rocks must be inferred. However, several observations suggest that these rocks were originally gabbros.

Bulk rock chemical composition. We have demonstrated that the range of chemical compositions of the 19 studied gneissic amphibolites overlaps that of the oceanic gabbros and metagabbros from the same region of the Mid-Atlantic Ridge.

Dredge haul composition. Dredge haul CH78Dr10 collected abundant serpentinites and gneissic amphibolites, a few gabbros, and no basalt. In dredge haul P7003-19, basalts were scarce, while 


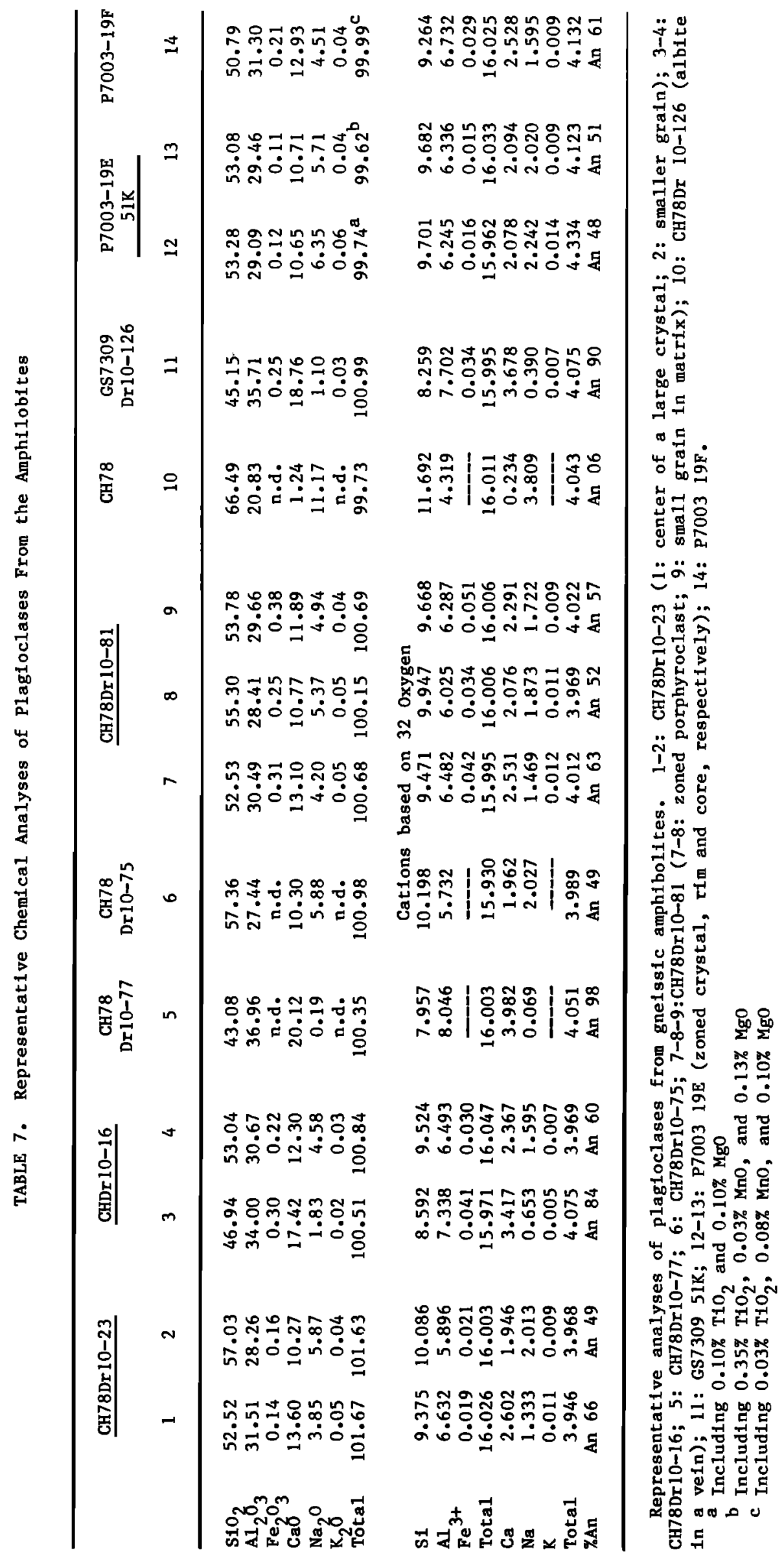


TABLE 8. Bulk Rock Analyses of Amphibolites

\begin{tabular}{|c|c|c|c|c|c|c|c|c|c|c|c|}
\hline & $\begin{array}{c}\text { CH78 } \\
\text { Dr10 } \\
126\end{array}$ & $\begin{array}{c}\text { CH78 } \\
\text { Dr } 10 \\
13\end{array}$ & $\begin{array}{c}\text { CH78 } \\
\text { Dr } 10 \\
14\end{array}$ & $\begin{array}{c}\text { CH78 } \\
\text { Dr } 10 \\
16\end{array}$ & $\begin{array}{c}\text { CH78 } \\
\text { Dr } 10 \\
18\end{array}$ & $\begin{array}{c}\text { CH78 } \\
\text { Dr } 10 \\
20\end{array}$ & $\begin{array}{c}\text { CH78 } \\
\text { Dr } 10 \\
23\end{array}$ & $\begin{array}{c}\text { CH78 } \\
\text { Dr10 } \\
75\end{array}$ & $\begin{array}{c}\text { CH78 } \\
\text { Dr } 10 \\
77\end{array}$ & $\begin{array}{c}\text { CH78 } \\
\text { Dr } 10 \\
81\end{array}$ & $\begin{array}{c}\text { CH78 } \\
\text { Dr } 10 \\
82\end{array}$ \\
\hline \multirow[t]{2}{*}{$\begin{array}{l}\mathrm{S1}_{2} \\
\mathrm{TiO}_{2} \\
\mathrm{Al}_{2} \mathrm{O}_{3} \\
\mathrm{Fe}_{2} \mathrm{O}_{3} \\
\mathrm{FeO} \\
\mathrm{MnO} \\
\mathrm{MgO} \\
\mathrm{CaO} \\
\mathrm{Na}_{2} \mathrm{O} \\
\mathrm{K}_{2} \mathrm{O} \\
\mathrm{I}_{\text {LL. }} \\
\text { Total }\end{array}$} & $\begin{array}{r}49.08 \\
0.81 \\
15.76 \\
2.67 \\
6.92 \\
0.09 \\
7.63 \\
10.92 \\
2.78 \\
0.49 \\
2.70 \\
99.76\end{array}$ & $\begin{array}{r}50.90 \\
0.78 \\
15.50 \\
1.86 \\
7.20 \\
0.18 \\
7.39 \\
11.33 \\
2.68 \\
0.17 \\
1.42 \\
99.41\end{array}$ & $\begin{array}{r}50.01 \\
1.09 \\
14.57 \\
2.86 \\
7.20 \\
0.18 \\
7.43 \\
11.32 \\
3.02 \\
0.16 \\
1.71 \\
99.55\end{array}$ & $\begin{array}{r}46.96 \\
2.07 \\
13.46 \\
3.29 \\
8.48 \\
0.20 \\
8.66 \\
12.23 \\
2.08 \\
0.14 \\
2.01 \\
99.58\end{array}$ & $\begin{array}{r}51.45 \\
0.64 \\
14.89 \\
2.71 \\
6.76 \\
0.15 \\
6.79 \\
10.87 \\
3.40 \\
0.15 \\
1.65 \\
99.46\end{array}$ & $\begin{array}{r}49.71 \\
1.02 \\
15.89 \\
3.09 \\
6.37 \\
0.34 \\
7.13 \\
11.18 \\
3.02 \\
0.14 \\
1.74 \\
99.63\end{array}$ & $\begin{array}{r}50.63 \\
1.14 \\
14.06 \\
2.58 \\
7.38 \\
0.15 \\
7.18 \\
11.86 \\
2.95 \\
0.12 \\
1.47 \\
99.52\end{array}$ & $\begin{array}{r}42.81 \\
4.88 \\
11.40 \\
10.54 \\
8.87 \\
0.28 \\
6.80 \\
10.09 \\
2.32 \\
0.17 \\
1.60 \\
99.73\end{array}$ & $\begin{array}{r}45.07 \\
0.86 \\
14.19 \\
4.36 \\
6.83 \\
0.16 \\
9.23 \\
15.03 \\
1.80 \\
0.15 \\
2.25 \\
99.96\end{array}$ & $\begin{array}{r}43.37 \\
5.00 \\
12.16 \\
5.46 \\
12.27 \\
0.20 \\
6.83 \\
9.98 \\
2.30 \\
0.13 \\
2.24 \\
99.94\end{array}$ & $\begin{array}{r}48.76 \\
1.77 \\
14.01 \\
3.81 \\
8.09 \\
0.16 \\
7.24 \\
11.34 \\
2.75 \\
0.10 \\
1.61 \\
99.64\end{array}$ \\
\hline & $\begin{array}{c}\text { CH78 } \\
\text { Dr10 } \\
83\end{array}$ & $\begin{array}{c}\text { CH78 } \\
\text { Dr10 } \\
87\end{array}$ & $\begin{array}{c}\text { CH78 } \\
\text { Dr10 } \\
127\end{array}$ & $\begin{array}{c}\text { CH78 } \\
\text { Dr10 } \\
128\end{array}$ & $\begin{array}{c}\mathrm{CH} 78 \\
\text { Dr10 } \\
129\end{array}$ & $\begin{array}{c}\text { P7003 } \\
19 \mathrm{E}\end{array}$ & $\begin{array}{c}\mathrm{P} 7003 \\
19 \mathrm{~F}\end{array}$ & $\begin{array}{c}\text { GS } \\
7309 \\
51 \mathrm{~K}\end{array}$ & $\begin{array}{c}\text { P7003 } \\
\text { 19AA } \\
\text { host }\end{array}$ & $\begin{array}{c}\text { P7003 } \\
\text { 19AA } \\
\text { Vein in } \\
\text { Meta- } \\
\text { gabbro }\end{array}$ & \\
\hline $\begin{array}{l}\mathrm{SiO}_{2} \\
\mathrm{TiO}_{2} \\
\mathrm{Al}_{2} \mathrm{O}_{3} \\
\mathrm{Fe}_{2} \mathrm{O}_{3} \\
\mathrm{FeO} \\
\mathrm{MnO} \\
\mathrm{MgO} \\
\mathrm{CaO} \\
\mathrm{Na}_{2} \mathrm{O}^{\mathrm{O}} \\
\mathrm{K}_{2} \mathrm{O} \\
\mathrm{H}_{2} \mathrm{O}^{\mathrm{O}} \\
\mathrm{P}_{2} \mathrm{O}_{5} \\
\mathrm{Tota}\end{array}$ & $\begin{array}{c}50.81 \\
1.21 \\
13.97 \\
4.12 \\
6.75 \\
0.45 \\
6.27 \\
9.41 \\
3.96 \\
0.18 \\
2.33 * \\
\text { n.d. } \\
99.46\end{array}$ & $\begin{array}{r}48.80 \\
1.85 \\
15.33 \\
2.50 \\
7.76 \\
0.15 \\
7.73 \\
10.66 \\
2.78 \\
0.09 \\
2.49 \\
0.06 \\
100.20\end{array}$ & $\begin{array}{r}49.43 \\
1.58 \\
14.50 \\
2.19 \\
8.44 \\
0.16 \\
8.33 \\
10.54 \\
2.50 \\
0.06 \\
2.12 \\
0.04 \\
99.89\end{array}$ & $\begin{array}{r}49.70 \\
2.00 \\
14.83 \\
1.57 \\
8.08 \\
0.15 \\
8.92 \\
10.46 \\
2.50 \\
0.09 \\
2.23 \\
0.03 \\
100.56\end{array}$ & $\begin{array}{r}50.93 \\
0.86 \\
16.05 \\
1.65 \\
6.72 \\
0.16 \\
7.93 \\
10.89 \\
2.85 \\
0.13 \\
1.78 \\
0.05 \\
100.00\end{array}$ & $\begin{array}{r}38.06 \\
8.79 \\
11.78 \\
3.64 \\
13.22 \\
0.23 \\
9.82 \\
8.80 \\
2.21 \\
0.11 \\
2.13 \\
0.01 \\
98.79\end{array}$ & $\begin{array}{r}45.92 \\
1.30 \\
10.00 \\
2.36 \\
9.60 \\
0.20 \\
12.58 \\
11.85 \\
1.75 \\
0.23 \\
3.03 \\
0.04 \\
98.86\end{array}$ & $\begin{array}{r}46.00 \\
0.30 \\
17.38 \\
1.06 \\
4.48 \\
0.08 \\
11.47 \\
16.07 \\
1.42 \\
0.04 \\
2.70 \\
0.03 \\
101.03\end{array}$ & $\begin{array}{r}42.14 \\
6.66 \\
11.06 \\
5.79 \\
12.29 \\
0.30 \\
6.16 \\
10.47 \\
2.69 \\
0.14 \\
2.65 \\
0.02 \\
100.37\end{array}$ & $\begin{array}{r}40.93 \\
5.22 \\
10.98 \\
3.47 \\
15.11 \\
0.25 \\
7.76 \\
9.67 \\
2.77 \\
0.24 \\
3.23 \\
0.04 \\
99.67\end{array}$ & \\
\hline
\end{tabular}

serpentinites, gabbros, and metagabbros were very abundant. We have demonstrated that the complete transition exists between undeformed gabbros to gneissic amphibolites from the latter dredge haul. Both dredge hauls are part of a sampling sequence of eight dredge hauls along both the north and south face of the transverse ridge of the Vema Fracture Zone, at about $43^{\circ} \mathrm{W}$.

Occurrence of apatite. In several samples of gnelssic amphibolite, apatite occurs as small grains linting up along the foliation. Th1s mineral is abundant in differentiated $F e$, Ti-rich gabbros from the higher levels of the magma chamber in the oceanic crust [Bonatti et al., 1971; Prinz et al., 1976; Ohnenstetter and Ohnenstetter, 1980]. These grains may be relict broken magmatic crystals preserved through amphibolite facies metamorphism.

Depth of dredging. The gneissic amphibolites have been dredged from 2050 to $2850 \mathrm{~m}$ below the crest of the transverse ridge. This observation is consistent with the abundance of differentiated gabbroic rocks such as numerous $\mathrm{Fe}, \mathrm{Ti}-\mathrm{rlch}$ gabbro norites and leuco-ferrodiorite in the upper part of magma chambers in the oceanic crust. However, this argument should be regarded with caution be- cause important vertical uplifts took place along the southern wall of the Vema Fracture Zone [Honnorez et al., 1975].

\section{Temperature Conditions}

The mineral assemblage observed in the gneissic amphibolites is typlcal of the amphibolite facies: hornblende + Ca-plagloclase \pm 1lmenite \pm clinopyroxene. That the rocks have reached equilibrium in most cases is demonstrated by the absence of igneous relics, the homogeneous composition of secondary minerals, and the partitioning of $\mathrm{Fe}$ and $\mathrm{Mg}$ between hornblende and clinopyroxene (Figure. 10b). According to Liou et al. [1974] the amphibolite facles sensu stricto (coexisting calcic plagloclase and hornblende) begins approximately at $550^{\circ} \mathrm{C}$ at low pressure. From the titanium content of the hornblendes (Raase, 1974) it is reasonable to estimate equilibrium temperature to be between $550^{\circ}$ and $650^{\circ}$. In the mylonitic amphibolites the minerals of the matrix are similar in composition to the porphyroclasts. Therefore it can be inferred that the mylonitization occurred within the same temperature range as the amphibolite factes recrystallization, the 


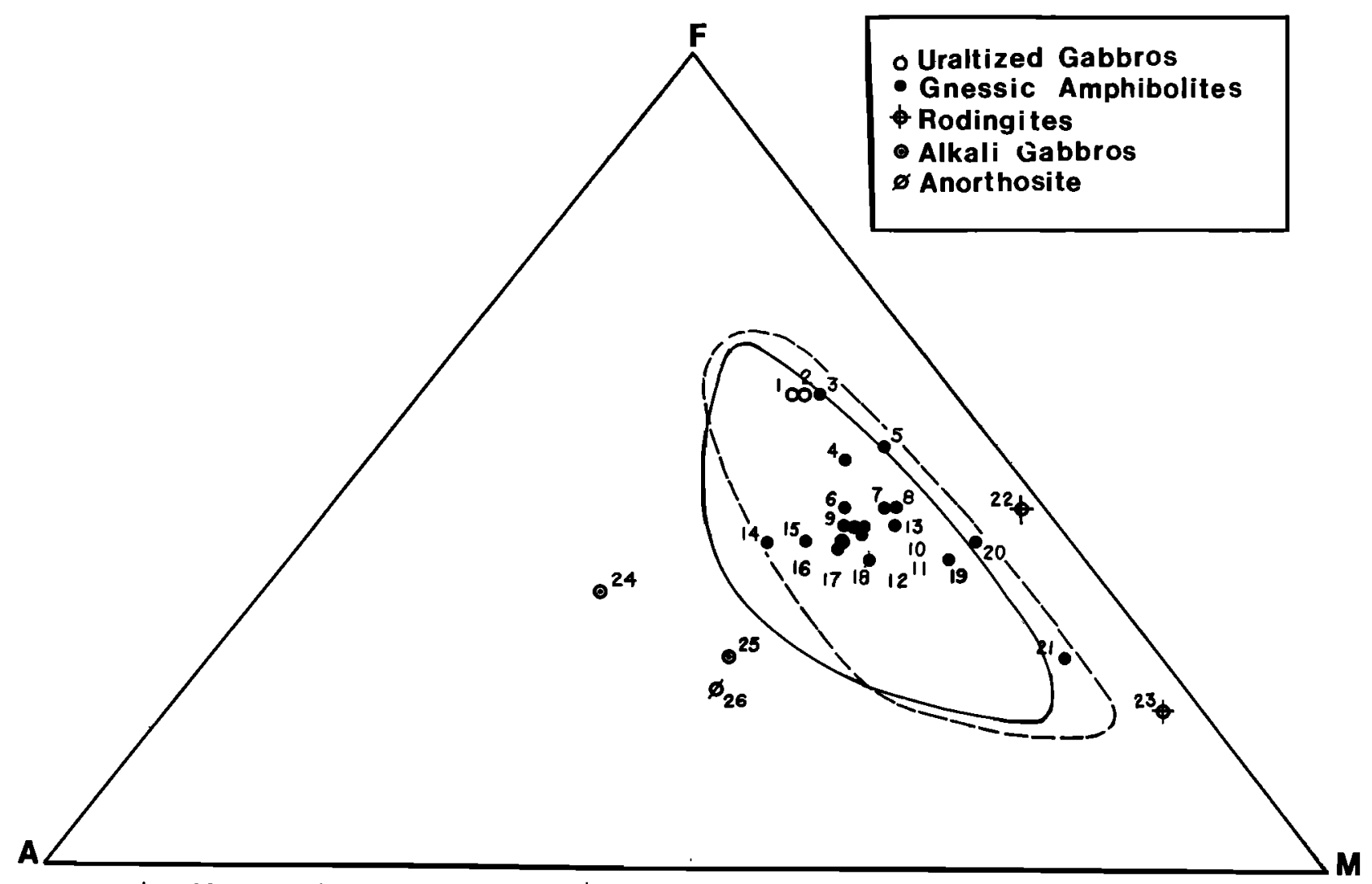

F1g. 11. AFM diagram of the gneissic amphibolites from the Vema and Romanche fracture zones compared to gabbros and metagabbros from the Mid-Atlantic Ridge. Solid line surrounds the field of the metagabbros [Honnorez and K1rst, 1975; Bonatt1 et a1., 1975; J Honnorez, unpublished data, 19XX]. Dashed line surrounds the field of the gabbros [J.Honnorez, unpublished data, 19XX; Pr1nz et al., 1976; Miyashiro and Sh1do,1980]. 1, uralitized gabbro P7003-19AA; 2, vein In gabbro P7003-19AA; 3, gneissic amphibolite CH78Dr10-81; 4, gnelssic amphibolite CH78Dr10-75; 5, gneissic amphibolite P7003-19E; 6, gneissic amphibolite CH78Dr10-82; 7, gneissic amphibolite CH78Dr10-127; 8, gneissic amphibolite CH78Dr10-16; 9, gnelssic amph1bolite CH78Dr10-14; 10, gneissic amphibolite CH78Dr10-13; 11, gnelssic amphibolite CH78Dr10-23; 13, gnelssic amphibolite CH78Dr10128; 14, gneissic amphibolite CH78Dr10-83; 15, gnelssic amphibolite CH78Dr10-18; 16, gneissic amphibolite CH78Dr10-20; 17, gnelssic amphibolite CH78Dr10-126; 18, gneissic amphi-bol1te CH78Dr10-129; 19, gne1ssic amph1bo11te CH78Dr10-77; 20, gneissic amphibolite P7003-19F; 21, gneissic amphibolite GS7309-51K; 22, rodingite P7003-23B; 23, roding1te P7003-17R; 24, alkal1 gabbro GS7309-; 24A; 25, alkal1 gabbro P6707-25F; 26, anorthosite GS7309-5BII.

only difference being the intensity and/or duration of shearing.

The low-temperature metamorphic minerals (smectite, actinolite, albite, prehnite, chlorite, quartz, ep1dote, sphene) observed in late veins correspond to greenschist facles conditions and lower temperatures formed during cooling of the 1ithosphere after shearing of these rocks stopped.

The presence in the associated metagabbros of igneous relict minerals and textures and the large varlety of secondary amphiboles (pargasitic hornblende, hornblende, actinolite) occurring in a single specimen demonstrate a lack of equilibrium related to a complex cooling story. The frequence of an inner actinolite rim separating the igneous pyroxene from the hornblende and the scarcity of metamorphic hornblende rims directly surrounding pyroxene rellcts suggest that the gabbros had a1ready cooled down to temperatures corresponding to the greenschist facies before starting to recrystal11ze Into amphibolites.

\section{Heat Source}

Let us consider now the possible heat sources present in the oceanic crust.

1. Magmatic activity at (or close to) spreadIng centers 18 the most logical and most often cited heat source. The hydrothermal circulation resulting from the warming up of seawater by the tholelitic magma would be responsible for the heat necessary to form the oceanic amphibolites.

2. Off axis basaltic rocks with alkaline tendencies(Bonatti et $a 1 ., 1979$ ) are really emplaced along fracture zones.. Such rocks were recovered from the St. Paul Fracture Zone [Melson et al., 1967] and the Romanche Fracture Zone (J. Honnorez 
TABLE 9. $\mathrm{K} / \mathrm{Ar}$ Ages

\begin{tabular}{|c|c|c|c|c|c|}
\hline \multirow[b]{2}{*}{ Sample } & \multirow[b]{2}{*}{ Mineral } & \multirow{2}{*}{$\begin{array}{c}\mathrm{k}^{2} \mathrm{o} \\
(w t \%)\end{array}$} & \multirow{2}{*}{$\begin{array}{c}{ }^{40} \mathrm{Ar} \mathrm{rad} \\
\left(10^{-11} \mathrm{~mole} / \mathrm{g}\right)\end{array}$} & ${ }^{40} \mathrm{Ar} \mathrm{rad}$ & \multirow[b]{2}{*}{ Age $\pm 1 \sigma, \mathrm{Ma}$} \\
\hline & & & & 40 Ar tota1 & \\
\hline Dr 10-81 & $\begin{array}{r}\text { amphibole } \\
(80-160 \mathrm{~m})\end{array}$ & 0.089 & 0.09986 & 2.27 & $7.8 \pm 3.7$ \\
\hline \multirow[t]{3}{*}{ Dr 10-83 } & $\begin{array}{l}\text { amphibole } \\
(80-160 \text { im) }\end{array}$ & 0.095 & 0.1796 & 6.52 & $13.1 \pm 1.8$ \\
\hline & $\begin{array}{l}\text { plagioclase } \\
(80-160 \mathrm{~m})\end{array}$ & 0.184 & 0.5229 & 2.01 & $19.6 \pm 4.1$ \\
\hline & $\begin{array}{l}\text { whole rock } \\
(250-350 \mathrm{~mm})\end{array}$ & 0.126 & 0.2703 & 5.71 & $14.8 \pm 1.5$ \\
\hline \multirow[t]{2}{*}{ Dr 10-16 } & $\begin{array}{l}\text { amph1bole } \\
(80-160 \mathrm{~m})\end{array}$ & 0.080 & 0.1111 & 6.78 & $9.6 \pm 1.5$ \\
\hline & $\begin{array}{l}\text { Plagioclase } \\
(80-160 \mu \mathrm{m})\end{array}$ & 0.157 & 0.2470 & 4.92 & $10.9 \pm 2.5$ \\
\hline Dr $10-20$ & $\begin{array}{l}\text { amphibole } \\
(50-71 \mathrm{\mu m})\end{array}$ & 0.091 & 0.09281 & 2.19 & $7.1 \pm 2.3$ \\
\hline Dr 10-77 & $\begin{array}{l}\text { amph1bole } \\
(90-112 \mathrm{~m})\end{array}$ & 0.093 & 0.1148 & 5.17 & $8.6 \pm 1.4$ \\
\hline Dr $10-23$ & $\begin{array}{l}\text { whole rock } \\
\text { (not crushed) }\end{array}$ & 0.080 & 0.2056 & 7.58 & $17.8 \pm 1.6$ \\
\hline
\end{tabular}

Analysts R. Montigny and R. Thuizat (I.P.G. Strasbourg). $\lambda_{\varepsilon}=0.581 \times 10^{-10} \mathrm{yr}^{-1} ; \lambda_{\beta}=4.962$ $\times 10^{-10} \mathrm{yr}^{-1} ; 40_{\mathrm{K} / \mathrm{K}_{\text {total }}}=1.167 \times 10^{-4} \mathrm{~mol} / \mathrm{mol}$.

and E. Bonatt1, unpublished data, 1978) but none were found from the Vema Fracture Zone.

3. The heat for metamorphism could be developed mechanically during shearing along the transform fault zone. Reitan [from Hyndman 1972] calculated that friction distributed through $3 \mathrm{~km}$ of crust during a relatively short period of time (1.e., $10^{5}$ to $10^{6}$ years) may raise the temperature through several kilometers of crust by about $30^{\circ}-$ $80^{\circ} \mathrm{C}$.

4. We must also consider the possibility of contact metamorphism by a high-temperature ultramafic intrusion because the gneissic amphibolites and related metagabbros are associated with serpentintes in both dredge hauls from the south wall of the Vema Fracture Zone. This wall belongs to a transverse ridge which is considered by some authors as an ultramafic diapiric protrusion [Bonatti and Honnorez, 1971, 1976; Bonatti, 1976, 1978].

The combination of shearing-induced heat with magmatic intrusion driven hydrothermal heat at spreading center was already advocated by Bonatti et al. [1975] to explain the formation of metagabbros from the crest of the Mid-Atlantic Ridge, at $6^{\circ} \mathrm{N}$. The metamorphic process which generated them was called "contact-hydrothermal-dynamic metamorphism."

Shearing

The gnetssic rocks are also characterized by crystallization under stress. The lack of field relationships for rocks dredged from the ocean floor makes the interpretation of their foliated textures difficult. Therefore, although many ophiolites probably did not form at typical midocean ridges, the study of metamorphic rocks in ophiolite sequences is helpful in understanding the oceanic metamorphic processes. In ophiolite complexes, oceanic metamorphism is mainly recorded as static, having occurred in the absence of stress [Spooner and Pyfe, 1973; Gass and Smewing, 1973; Meve1, 1975; E1thon and Stern, 1978; Colsh, 1977; Stern and E1thon, 1979; Liou and Ernst, 1979]. However, some examples of follated metamorphic rocks have been described, usually in the gabbro sequence. From field relationships they seem to result from two main types of processes:

Type 1. Horizontal localized shear zones may induce the formation of flaser gabbros and gneissic amphibolites, with a foliation subparallel to the layering in the gabbro sequence. They probably form close to the ridge axis by ductile deformation of the still hot crust and are therefore related to the spreading. Such rocks occur, for instance, in the Apennines [Cortesogno et al., 1975], in the western Alps [Mevel et al., 1978; Steen et ai., 1980], at Canyon Mountain [Thayer, 1980 and personal communication, 1982], in the Dun Mountain belt, New Zealend [K1dd, 1981], and in Newfoundland [G1rardeau, 1979; Casey et a1., 1981; Girardeau and Méve1, 1982]. In Newfoundland, minor vertical shear zones, subparallel to the mean dike trend, are interpreted as resulting from the formation of the rift valley walls [Casey et a1., 1981].

Type 2. Larger amphibolite bodies may be related to mafor accidents such as transform faults. In this case, the shearing should be vertical. Such rocks have been described in the Coastal Complex, Newfoundland [Karson and Dewey, 1978; Casey et al., 1981] and In Oman [Smew1ng, $1980]$.

In situ observations from submersibles describe planar structures in oceanic layer 3. They are interpreted as shear zones because gneissic rocks have actually been sampled from these zones. But 
TABLE 10. Water Contents of Gneissic Amphibolites, Gabbros, Metagabbros, and Rodingites From the Mid-Atlantic Ridge Fracture Zones

\begin{tabular}{|c|c|c|c|c|}
\hline $\begin{array}{l}\text { Average } \\
\mathrm{H}_{2} \mathrm{O+}, \\
\%^{2}\end{array}$ & $\begin{array}{c}\mathrm{H}_{2} \mathrm{O+} \\
\text { Range, } \\
\%\end{array}$ & $\begin{array}{l}\text { Number } \\
\text { of } \\
\text { Samples }\end{array}$ & References & \\
\hline $\begin{array}{l}\text { Unaltered and silghtly } \\
\quad \text { uralitized gabbros } \\
\text { Gneissic amphibolites } \\
\text { Metagabbros } \\
\text { Rodingites }\end{array}$ & $\begin{array}{l}1.5 \\
2.1 \\
3.7 \\
9.3\end{array}$ & $\begin{array}{l}0.84-1.71 \\
1.21-3.03 \\
1.51-8.79 \\
7.10-11.55\end{array}$ & $\begin{array}{l}8 \\
19 \\
40 \\
2\end{array}$ & $\begin{array}{l}\text { Prinz et al. [1976] and } \\
\text { J. Honnorez (unpublished data, 1979) } \\
\text { this paper } \\
\text { Bonatti et al. [1975] and } \\
\text { J. Honnorez (unpublished data, 1979) } \\
\text { Honnorez and Kirst [1975] }\end{array}$ \\
\hline
\end{tabular}

their orlentation is variable: it has a wide range in the Cayman trough [Stroup and Fox, 1981], is mostly subhorizontal in the Gorringe bank [CYAGOR Group, 1984], and 1s vertical and parallel to the ridge axis in the Kane fracture zone (H. J. B. D1ck, personal communication, 1983). All these shear zones seem to be related to type 1 .

In the absence of direct observation it is $1 \mathrm{~m}-$ possible to conclude anything about the origin of the shearing observed in the Vema Fracture Zone rocks. However, the abundance and the large size of the gneissic amphibolite samples (one dredge haul contalned half amphibolites, half serpentinites, and almost no gabbro) as well as the fact that these rocks occur in two dredged hauls taken $15 \mathrm{~km}$ away from each other seem to preclude narrow shear zones in mostly undeformed gabbros. We think rather that the gneissic amphibolites were formed in a large vertical shear zone related to the transform fault activity as in type 2 .

\section{Origin of Water}

The gnelssic amphibolites are richer in water than gabbros and poorer in water than metagabbros from the Mid-Atlantic Ridge and its fracture zones (see Table 10). This intermediate water content is related to the presence of hornblende which contains less water than lower-grade metamorphic phases.

According to Lister [1982], seawater percolates through the oceanic crust along a "cracking front" during the "active stage" of the crust cooling. The depth and temperature of thls front are related to the temperature at which the crustal rocks are sufficlently stressed to crack. This cracking temperature is still unknown because of poor knowledge of the mechanical behavior of oceanic rocks. However, one can assume that the cracking front and, consequently, the hydrothermal metamorphism, reach down to a zone of the oceanic crust directly overlying the magma chamber and, later, farther down through the now solid magma chamber itself. At such time, the hydrothermal circulation and alteration have decreased in intensity ("passive stage") because most of the heat has already been lost by the now solid gabbros. Lister's theory seens to be confirmed by the observation that in several ophiolite complexes, massive gabbros and even part of the underlying cumulate gabbros are hydrothermally altered, whereas the major part of the more deeply seated layered gabbros appears to be fresh.

The fact that all of the metagabbros and amphibolltes dredged from the seafloor contain about 10 times more atmospheric argon than fresh başlt glass $\left(0.35 \times 10^{-8}\right.$ versus $0.035 \times 10^{-8} \mathrm{~cm}^{3}$ of ${ }^{36} \mathrm{Ar}$ (D.E. Fisher, personal communication, 1983) indicate that the plutonic rocks and their metamorphic equivalent reacted with seawater.

It has been pointed out that the hornblendes from gnelssic amphibolites contaln no chlorine and generally less sodium (see Figure 9) than those from assoctated metagabbros which may contain an appreclable amount of chlorine. Similarly, in the partly amphibolitized metagabbros from the MidCayman Rise [Ito and Anderson, 1983] the most C1rlch hornblendes with up to $0.66 \% \mathrm{Cl}$ occur just below the crustal level where the most altered gabbros were collected. This may indicate, according to Ito and Anderson, the formation of a dense brine seal in the crust during metamorphism. As suggested by Ito [1979] and Ito and Clayton [1983], of the basis of water/rock ratios calculated from $180 /{ }^{16} 0$ the composition of the fluid phase evolves toward water deficlent brines as it reacts with the crust. This suggests that the fluld phase responsible for the crystallization of chlorine-rich amphiboles in the metagabbro was more evolved (1.e., had lost more water) than the solution reacting to form the gneissic amphibolites.

The lack of magnetite and the presence of ilmenite in the gneissic amphibolites indicate that relatively low oxygen fugacity prevalled during metamorphism. Most of the iron of the parental gabbros entered the hornblende (and eventually the clinopyroxene) as $\mathrm{Fe}^{2+}$. Minor amounts of $\mathrm{Fe}^{2+}$ also entered the accessory I1menite whose abundance was determined by the titanium content of the rock. This is the reason why the hornblendes from the gneissic amphibolites are relatively rich in Iron (1.014 to $2.874 \mathrm{~mol}$ $\mathrm{Fe}^{\mathrm{T}}$ per half unit cel1).

\section{Age of Metamorphism}

Dredge hauls CH78Dr10 and P7003-19 recovered the gneisalc amphibolite at about 196 and $207 \mathrm{~km}$, respectively, from the spreading axis of the MidAtlantic Ridge. Ages of crustal emplacement of 12.3 or 14 m. $y_{\bullet}$, and 13 or 14.8 m.y., respective$1 y$, are calculated using the Minster and Jordan [1978] 1.6 or $1.4 \mathrm{~cm} / \mathrm{yr}$ half spreading rate values 
between South America and Africa or North America and Africa, respectively. Within the limit of analytical errors, K/Ar datings of gneissic amphibolite bulk rocks and isolated phases are, on the whole, consistent with the calculated ages of the crust. This means that the amphibolites were generated in the vicinity of the ridge axis. However, this inference does not help us to determine whether the metamorphic event affected newly emplaced gabbrolc rocks or older gabbros forming a stagnant block which would have been rejuvenated as it moved past the spreading center.

Conclusion: Formation of the Gnelssic Amphibolites and Assoclated Metagabbros in the Vema Fracture Zone

We have demonstrated that the gneissic amphibolites from the Vema Fracture Zone were derived from various types of oceanic gabbroic rocks. Most of them were dredged from about $3 \mathrm{~km}$ subbottom, while metagabbros and flaser gabbros were dredged from shallower depths (1.e., between 2 and $3 \mathrm{~km}$ ). Their mineral assemblage shows that the rocks equilibrated in the amphibolite facies conditions which require a thermal gradient of 200 to $320^{\circ} / \mathrm{km}$. The depths at which the gneissic amphibolites were dredged have obviously no signiflcance for calculating thermal gradient in the ocean crust during the amphibolite facies metamorphic event. Their strong follation implies stress during recrystallization. Transform zones are characterized by intense shearing along vertical planes subparallel to the direction of spreading. The friction and mostly some magmatic intrusions are the most likely heat sources in these zones. We suggest that the fault zone may have acted as the condult of the ascendant $11 \mathrm{mb}$ of a hydrothermal convective cell. At depths of several k1lometers subbasement the stress combined with the hydrothermal circulation induces the ductile deformation and equilibrium recrysta1lization of the gabbros in amphibolite facies conditions. As the fluid phase reacts and ascends, it cools down and its composition evolves toward $\mathrm{Na}$, Cl-rich brines. These cooler and strongly modified fluids in comparison with seawater react with the overlying gabbros (which have already cooled down as evidenced by the partial replacement of pyroxene by actinolite) to form the chlorine-rich amphiboles in the flaser gabbros of the sheared zones and in the less deformed metagabbros farther away from these sheared zones.

Subsequent1y, the stress is released, and the hydrothermal activity fades out forming late veins with greenschist facies minerals. This retrometamorphic event could happen when the amphibolites and metagabbros are uplifted toward their present location by vertical tectonism to become parts of the transverse ridge.

The age of the metamorphism is uncertain because of the analytical errors due to the low $k$ content of the amphibolites. One can nevertheless conclude from the K/Ar datings that the metamorphic event took place in the vicinity of the spreading center and either affected the newly emplaced oceanic gabbros or preexlsting crustal rocks forming a "stagnant" transverse ridge.

As transform faults regularly offset midoceanic ridges and more particularly slow spreading ridges such as the Mid-Atlantic Ridge, gnelssic amphibolites are likely to be a common, if not abundant, constltuent of oceanic layer 3 . The near absence of amphibolite facles metabasalts is probably due to the difficulty of oceantc layer 2 rocks to reach the high-temperature regime required for their ductile deformation and recrystal1ization.

Acknowledgments. We extend our appreciation to the officers and the crews of the $R / V$ PIIlsbury and Jean Charcot for their collaboration during legs $\mathrm{P7003}$ and $\mathrm{CH78}$, respective1y, to the Vema Fracture Zone. We are grateful to $\mathrm{E}$. Bonatti and D. Needham for allowing us to study the samples of gneissic amphibolites dredged during these two legs. We also wish to thank A. Anderson, H. J. B. Dick, W. G. Ernst, D. E. Flsher, E. Ito, J. G. Llou, R. Kidd, J. R. Klenast and P. W. Kirst for stimulating discussions and reviews of this paper. This research was supported by grants from the National Science Foundation (OCE 79-09318) and the Centre National de la Recherche Scientifique (ATP-IPOD).

\section{References}

Aumento, F., B. C. Loncarevic, and D. I. Ross, Hudson geotraverse: Geology of the MidAtlantic Ridge at $45^{\circ} \mathrm{N}$, Philos. Trans. R. Soc. London Ser. A, 268, 623-650, 1971 .

Bodganov, Y. A., and V. V. Ploshko, Magmatic and metamorphic rocks of the deep-water Romanche trench, Dok1. Ak. Nauk SSSR, 177, 173-176, 1967.

Bonatti, E., Serpentinfte protrusions in the oceanic crust, Earth Planet. Sc1. Lett., 32, $107-113,1976$.

Bonatt1, E., Vertical tectonism in oceanic fracture zones, Earth Planet. Sc1. Lett., 37, 369-379, 1978.

Bonatt, E., and A. P. Chermak, Formerly emerging crustal blocks in the equatorial Atlantic, Tectonophysics, 72, 165-180, 1981 .

Bonatt1, E., and J. Honnorez, Non-spreading crustal blocks at the Mid-Atlantic Ridge, Sclence, 174, 1329-1331, 1971 .

Bonatt1, E., and J. Honnorez, Sections of the earth's crust in the equatorial Atlantic, J. Geophys. Res., 81, 4104-4116 (1976).

Bonatti, E., J. Honnorez, and G. Ferrara, Equatorial Mid-Atlantic Ridge: Petrological and $\mathrm{Sr}$ 1sotopic evidence for alpine-type rock assemblages, Earth Planet. Sc1. Lett., 9, 247256, 1970.

Bonatt1, E., J. Honnorez, and G. Ferrara, Peridotite-gabbros-basalt complex from the equatorial Mid-Atlantic Ridge, Philos. Trans. R. Soc. London Ser., A, 268, 385-402, 1971 .

Bonatti, E., C. Emilian1, G. Ferrara, J. Honnorez, and $H$. Rydell, Ultramafic carbonate breccias from the equatorial Mid-Atlantic Ridge, Mar. Geol., 16, 83-102, 1974.

Bonatti, $\overline{E_{0},}$ J. Honnorez, P. Kirst, and $P$. Radicati, Metagabbros from the Mid-Atlantic Ridge at $06^{\circ} \mathrm{N}$ : Contact-hydrothermal-dynamlc metamorphism beneath the axial valley, J, Geol., 83, 61-78, 1975.

Bonatti, E., A. Chermak, and J. Honnorez, Tectonic and Igneous emplacement of crust in oceanic transform zones, in Deep Drilling Results in the Atlantic Ocean: Ocean Crust, Maurice Ewlng Ser., vol.2, edited by M. Talwani, C. G. 
A. Harrison, and D. E. Hayes, pp. 239-248, AGU, Washington, D. C., 1979.

Cann, J. R., Spilites from the Carlsberg Ridge, J. Petrol., 10, 1-19, 1969.

Cann, J. R., A new model for the structure of the ocean crust, Nature, 226, 928-930, 1970.

Cann, J. R., Petrology of basement rocks from Palmer Ridge, NE Atlantic, Philos. Trans. R. Soc. London Ser., A, 268, 605-617, 1971.

Cann, J. R., Metamorphism in the ocean crust, in Deep Drilling Results in the Atlantic Ocean: Ocean Crust, Maurice Ewing Ser., edited by, M. Talwani, C. G. A. Harrison, and D. E. Hayes, D.E., pp. 230-238, AGU, Washington, D. C., 1979 .

Cann, J. R., and B. M. Funne11, Palmer Ridge: A section through the upper part of the ocean crust, Nature, 213, 661-664, 1967.

Cann, J. R., and F. J. Vine, An area on the crest of the Carloberg Ridge: Petrology and magnetic survey, Philos. Trans. R. Soc. London Ser., A, 259, 198-217, 1966 .

Casey, J. F., J. F. Dewey, P J. Fox, J. A. Karson, and $\mathrm{E}$. Rosencrantz, Heterogeneous nature of oceanic crust and upper mantle: A perspective from the Bay of Islands ophiolite complex, in The Sea, vol. 7, edited by C. Emillani, pp. 305-338, W1ley-Intergcience, New York, 1981.

Christensen, N. I., Composition and evolution of the oceanic crust, Mar. Geol., 8, 139-154, 1970.

Christensen, N. I., Selsmic anisotropy in the lower oceanic crust, Nature, 237, 450-451, 1972.

Christensen, N. I., and M. H. Salisbury, Structure and constitution of the lower oceanic crust, Rev. Geophys. Space Phys., 13, 57-86, 1975.

Colsh, R. A., Ocean-floor metamorphism in the Betts Cove ophiolite, Newfoundland, Contrib. Minera1. Petrol., 60, 255-270, 1977.

Cortesogno, L., G. Gianel11, and G. B. Piccardo, Preorogenic metamorphic and tectontc evaluation of the ophiolite mafic rocks (North Apennine and Tuscany), Bol1. Soc. Geol. Ita1., 94, 291-327, 1975.

Cox, A. and G. B. Dalrymple, Statistical analysis of geomagnetical reversal data and the precision of potassium argon dating, J. Geophys. Res., 72, 2603-2614, 1967.

CYAGOR Group, Gorringe Bank (Atlantic Ocean, S.W. Portugal): A section in deep oceanlc crust and upper mantle, in Ophiolites and Actualism, Florence, 18-19 December 1981, Ofioliti, in press, 1984.

Dalrymple, G. B., and M. A. Lamphere, Potassium argon dating, Freeman, San Francisco, Calif., 258 pp., 1969.

Elthon, D., and C. Stern, Metamorphic petrology of the Sarmiento ophiolite complex, Chile, Geology, 6, 464-468, 1978.

Ewing, J., and M. Ewing, Selsmic refraction profiles in the Atlantic Ocean basins, Mediterranean Sea, Mid-Atlantic Ridge and Norweglan Sea, Geol. Soc. Am. Bull.. 70, 291$318,1959$.

Fox, P. J., E. Schreiber, and J. J. Peterson, The Geology of the oceanic crust: Compressional wave veloctities of oceanic rocks, J. Geophys. Res., 78, 5155-5172, 1973.

Fox, P. J., E. Schrelber, H. Rowlett, and K. McCamy, The geology of the Oceanographer
Fracture Zone: A mode1 for fracture zones, J. Geophys. Res., 81, 4117-4128, 1976.

Francheteau, J., P. Choukroune, R. Hekinian, X. Le Pichon, and H. D. Needham, H.D. Oceantc fracture zones do not provide deep sections in the crust, Can. J. Earth Sci., 13, 1223-1235 , 1976.

Gass, I. G., and J. D. Smewing, Intrusion, extrusion and metamorphism at constructive margins: Evidence from the Troodos massif, Cyprus, Nature, 242, 26-29, 1973.

Girardeau, J., structures des ophiolites de 1 'ouest de Terre neuve et modele de croute océanique, these de Doctorat de 3eme cycle, 154 pp., Univ, de Nantes, Nantes France, 154 pp., 1979.

Girardeau, J., and C. Mevel, Shear zones in ophiolite cumulate gabbros as indicators of the evolution of the oceanic crust, Bay-ofIslands, Newfoundland, Earth Planet. Scl. Lett., 61, 151-165, 1982 .

Gutenberg, B., Physics of the Earth's Interior, Academic, New York, 1959.

Heezen, B. C., R. D. Gerard, and M. Tharp, The Vema Fracture Zone in the equatorial Atlantic, J. Geophys. Res., 69, 733-739, 1964.

Helmstaedt, H., J. M. Allen, Metagabbronorite from DSDP hole 334: An example of high temperature deformation and recrystallization near MidAtlant1c Ridge, Can. J. Earth Sc1., 280A, 269283, 1977.

Hess, H. H., The AMSOC hole to the earth's mantle, Eos Trans. AGU, 40, 340-345, 1959.

Honnorez, J., and E. Bonatti, Petrology and petrotectonic setting of the mylonites from the equatorial mid-Atlantic fracture zones, paper pesented at the IUGG XVI General Assembly, Grenoble, 1975.

Honnorez, J., and E. Ito, Significance of oceanic amphibolites, (abstract), Geol. Soc. Am. Abstr. Programs, 445, 1979.

Honnorez, J., and P. K1rst, Petrology of rodingites from the equatorial mid-Atlantic fracture zones and their geotectonic significance, Contrib. Mineral. Petrol., 46, 233-257, 1975.

Honnorez, J., P. W. Kirst, B. M. HonnorezGuerstein, E. Bonatti, and F. Radicat1, Petrology and geotectonic significance of true amphibolites from the Romanche and Vema fracture zones, equatorial mid-Atlantic, paper pesented at IASPEI/IAVCEI Assembly, Durham, 1977.

Honnorez, J., E. Bonatti, C. Emilianl, P. Brơnnimann, M. A. Furrer, and A. A. Meyerhoff, Mesozolc limestone from the Vema offset zone, Earth Planet. Sc1. Lett., 26, 8-12, 1975.

Humphris, S. E., and G. Thompson, Hydrothermal alteration of oceanic basalts by seawater, Geoch1m. Cosmoch1m. Acta, 42,107-125, 1978.

Hyndman, D. W., Petrology of Igneous and Metamorph1c Rocks, 532 pp., McGraw-H111, New York, 1972.

Ito, E., High temperature metamorphism of plutonic rocks from the Mid-Cayman rise: A petrographic and oxygen isotopic study, Ph.D. thes1s, 158 pp., Untv. of Chicago, Ch1cago, I11., 1979.

Ito, E., and A. T. Anderson, Jr., Submarine metamorphism of gabbros from the Mid-Cayman rise: Petrographic and mineralogic constraints 
on hydrothermal processes at slow-spreading ridges, Contrib. Mineral. Petrol., 82, 371388,1983 .

Ito, E., and R. N. Clayton, Submarine metamorphism of gabbros from the Mid-Cayman rise: An oxygen isotopic study, Geochim. Cosmochim. Acta, 47, 535-546, 1983.


des roches oceaniques de l'Atlantique nord, these de Docteur-Ingenieur, Univ. de Nancy I, Nancy, France, 1975.

Karson, J., and J. F. Dewey, Coastal complex, western Newfoundland: An early ordovician oceanic fracture zone, Geol. Soc. Am. Bull., 89, 1037-1049, 1978.

Kidd, R. G. W., Coeva1 magmatism and amphibolite facles metamorphism in the oceanic crust, Eos Trans. AGU, 62, 1088, 1981.

Kirst, P., Petrology of metamorphic rocks from the equatorial Mid-Atlantic Ridge and fracture zones, Ph.D. thesis, Univ. of Mlami, Miami, Fla., 1976.

Leake, B. E., Nomenclature of amphiboles, Min. Mag., 42, 533-543, 1978.

Liou, J. G., and W. G. Ernst, Oceanic ridge metamorphism of East Talwan ophiolite, Contr1b. Minera1. Petrol., 68, 335-348, 1979.

Liou, J. G., S. Kuniyoshi, and K. Ito, Experimental studies of the phase relation between greenschist and amphibolite in a basaltic system, Am. J. Sci., 274, 613-632, 1974.

Lister, C. R. B., "Active" and "passive" hydrothermal systems in the oceanic crust: Predicted physical conditions, in The Dynamic Environment of the Sea-floor, Heath, Lexington, Mass., 441-470, 1982.

Malcolm, F.L., Petrography and petrology of submersible collected gabbros from the MidCayman rise, Caribbean, M.S. thesis, State Univ. of N. Y. at Albany, Albany, 1979.

Matthews, D. H., F. J. Vine, and J. R. Cann, Geology of an area of the Carlsberg Ridge, Geo1. Soc. Am.Bul1., 76, 675-682, 1965.

Melson, W. G. and G. Thompson, Petrology of a transform fault zone and adjacent ridge segments, Philos. Trans. R. Soc. London Ser., A, 268, 423-441, 1971 .

Melson, W. G., E. Jarosevich, R. Cifelli, and G. Thompson, Alkall olivine basalt dredged near St. Paul's rocks, Mid-Atlantic Ridge, Nature, 215, 381-382, 1967.

Melson, W. G., G. Thompson, and T. Van Andel, Volcanism and metamorphism in the Mid-Atlantic Ridge, $22^{\circ} \mathrm{N}$ latitude, J. Geophys. Res., 73, $5925-5941,1968$.

Mevel, C., Les zonations chimiques dans les pillow-1avas spilitiques du Chenaillet et des Gets, Alpes françaises, Pétrologie, 1, 319$333,1975$.

Mevel, C., R. Caby, J. R. Rienast, Amphibolite facies conditions in the oceanic crust: Example of amphibolitized flaser gabbros and amphibolites from the Chenaillet ophiolite massif (Hautes A1pes, France), Earth Planet. Sci. Lett., 39, 98-108, 1978.

Minster, J. B., and T. H. Jordan, Present-day plate motion, J. Geophys. Res., B3, 5331-5354, 1978.

Miyashiro, A., and F. Shido, Differentiation of gabbros in the Mid-Atlantic Ridge, near $24^{\circ} \mathrm{N}$, Geochem. J., 14, 145-154, 1980.

Miyashiro, A., F. Shido, and M. Ewing, Metamorphism in the Mid-Atlantic Ridge near $24^{\circ}$ and $30^{\circ} \mathrm{N}$, Philos. Trans. R. Soc. London Ser. A, 268, 589-603, 1971.

Ohnenstetter, M. and and D. Ohnenstetter, Comparison between Corsican albitites and oceanic plagiogranites, Arch. Sc1., 33, 201220,1980

Ploshko, V. V., Y. A. Bogdanov, and D. N. Knyazeva, Gabbro-amfibolity glubovodnoy vpadiny Romansh (Atlantika), Dolk. Akad. Nauk SSSR, 192, 615-618, 1970.

Prichard, H. M. and J. G. Mitche11, K-Ar data for the age and evolution of Gettysburg Bank, North Atlantlc Ocean, Earth Planet Scl. Lett., 44, 261-268, 1979.

Prinz, M., K. Kell, J. A. Green, A. M. Reid, E. Bonatt1, and J. Honnorez, Ultramafic and mafic dredged samples from the equatorial MidAtlantic RIdge and fracture zones, J. Geophys. Res., 81, 4087-4103, 1976.

Raase, $\mathrm{P}_{.}, \mathrm{Al}$ and $\mathrm{Ti}$ contents of hornblende, Indicators of pressure and temperature of regional metamorphism, Contrib. Mineral. Petrol., 45, 231-236, 1974.

Raitt, R. W., The crustal rocks, in The Sea, vol. 3, edited by M.N. Hill, pp. 85-100, WileyInterscience, New York, 1963.

Reed, S. J. B. and N. G. Ware, Quantitative electron microprobe analysis of silicates using energy-dispersive X-ray spectrometry, J. Petrol., 16, 499-519, 1975.

Ruck1idge, J. and E. L. Gasparini, Electron microprobe analytical reduction EMPADR VII. Dep. of Geol., Univ, of Toronto, Toronto, Ont., 1969.

Sclater, J. G., R. N. Anderson, and M. L. Bell, Elevation of ridges and evolution of the central eastern Pacific, J. Geophys. Res., 76, $7888-7915,1971$.

Shido, F. and A. Miyashiro, Hornblendes of basic metamorphic rocks, J. Fac. Sc1. Univ. Tokyo Sect. 2, 12, 85-102, 1959 .

Smewing, J. D., An upper Cretaceous RIdgetransform intersection in the Oman ophiolite, in Proceedings International Ophiolite Symposium, Cyprus, pp. 407-413, Geologica1 Survey of Cyprus, Nicosia, 1980.

Spear, F. S., Ca-amphibole composition as a function of temperature, fluid pressure and oxygen fugacity in a basaltic system, annual report, pp. 776-779, Geophys. Lab., Carnegie Inst. , Washington, D. C., 1975.

Spooner, E. T. C., and W. S. Fyfe, Sub-sea floor metamorphism, heat and mass transfer, Contrib. Mineral. Petrol., 42, 286-304, 1973.

Steen, D. M., M. Vuagnat, and J. J. Wagner, Early deformations in Montgenevre gabbros, Collog. Int. C.N.R.S., $\mathrm{N}^{\circ} 212,97-103,1980$.

Steiger, R. H., and E. Jaeger, Subcommission on geochronology: Convention on the use of decay constants in geo and cosmochronology. Earth Planet. Sc1. Lett., 36, 359-362, 1977.

Stern, C., and D. Elthon, Vertical variations in the effects of hydrothermal metamorphism in Chilean ophiolites: Their implications for ocean floor metamorphism, Tectonophysics, 55, 179-213, 1979. 
Stroup, J. B. and P. J. Fox, Geologic investigations in the Cayman Trough: Evidence for thin oceanic crust along the Mid-Cayman Rise, J. Geol., 89, 395-420, 1981 .

Thayer, $T$.P., Peridotite-gabbro complexes as keys to petrology of mid-ocean ridges, Geol. Soc. Am. Bull., 80, 1515-1522, 1969.

Thayer, T. P., Syncrysta1lization and subsolidus deformation in ophiolitic peridotite and gabbro, Am. J. Sc1., 280A, 269-283, 1980.

Thompson, G., and W. G. Melson, The petrology of oceanic crust across fracture zones in the Atlantic Ocean: Evidence of a new kind of sea-floor spreading, J. Geol., 80, 526-538, 1972.

Van Ande1, T. H., Recent uplift of the MidAtlantic Ridge south of the Vema Fracture Zone, Earth P1anet. Sc1. Letters, 7, 228-230, 1969.
Van Andel, T. H., J. B. Corliss, and V. T. Bowen, The intersection between the Mid-Atlantic Ridge and the Vera Fracture Zone in the North Atlantic, J. Mar. Res., 25, 343-351, 1967.

Van Andel, T. H., R. P. von Herzen, and J. P. Phillips, The Vema Fracture Zone and the tectonics of transverse shear zones in oceanic crustal plates, Mar. Geophys. Res., 1, 251283,1971 .

Westphal, M., R Montigny, R. Thuizat, C. Bardon, A. Bossert, and R. Hamzeh, Paleomagnetisme et datation du volcanisme permien, triasique et crétace du Maroc, Can. J. Earth Sci., 16, 2150-2164, 1979.

(Recelved December 29, 1981;

revised May 8, 1984;

accepted May 24, 1984.) 